\title{
Geotechnical Analysis of Five Shelby Tube Samples from H-Area
} Retention Basin

by

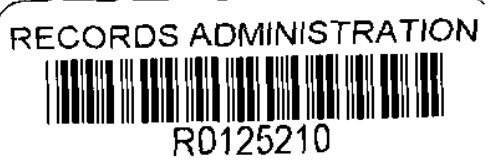

C. A. Langton

Westinghouse Savannah River Company

Savannah River Site

Aiken, South Carolina 29808

W. L. Mhyre

This paper was prepared in connection with work done under the above contract number with the U. S.

Department of Energy. By acceptance of this paper, the publisher and/or recipient acknowledges the U. S. Government's right to retain a nonexclusive, royalty-free license in and to any copyright covering this paper, along with the right to reproduce and to authorize others to reproduce all or part of the copyrighted paper. 


\section{DISCLAIMER}

This report was prepared as an account of work sponsored by an agency of the United States Government. Neither the United States Government nor any agency thereof, nor any of their employees, makes any warranty, express or implied, or assumes any legal liability or responsibility for the accuracy, completeness, or usefulness of any information, apparatus, product, or process disclosed, or represents that its use would not infringe privately owned rights. Reference herein to any specific commercial product, process, or service by trade name, trademark, manufacturer, or otherwise does not necessarily constitute or imply its endorsement, recommendation, or favoring by the United States Govemment or any agency thereof. The views and opinions of authors expressed herein do not necessarily state or reflect those of the United States Govemment or any agency thereof.

This report has been reproduced directly from the best available copy.

Available to DOE and DOE contractors from the Office of Scientific and Technical Information, P.O. Box 62, Oak Ridge, TN 37831; prices available from (615) 576-8401.

Available to the public from the National Technical Information Service, U.S. Department of Commerce, 5285 Port Royal Road, Springfield, VA 22161. 
Key Words: H-Area Retention Basin

Geotechnical Analysis

Soil Characterization

RETENTION: Permanent

GEOTECHNICAL ANALYSIS OF FIVE SHELBY TUBE SAMPLES

FROM THE H-AREA RETENTION BASIN (U)

\author{
Author \\ Christine A. Langton, \\ Westinghouse Savannah River Company \\ Savannah River Technology Center \\ Aiken, SC 29808 \\ And \\ W. L. Mhyre \\ Raytheon Engineers and Constructors \\ Savannah River Site \\ Aiken, SC 29808
}

Date: February 8, 1999

Westinghouse Savannah River Companv Savannah River Site

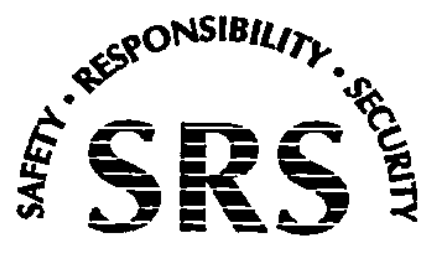


WSRC-TR-99-00057

Rev. 0

February 8, 1999

REVIEWS and APPROVALS

Authors

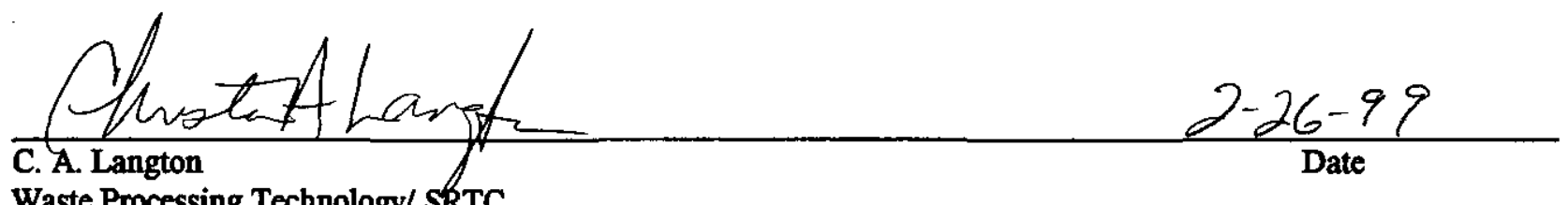

Waste Processing Technology/ SkTC

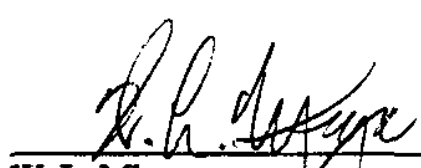

$3 / 03 / 99$

W. L. Mhyre Raytheon Engineers \& Constructors

Approvals/Reviews

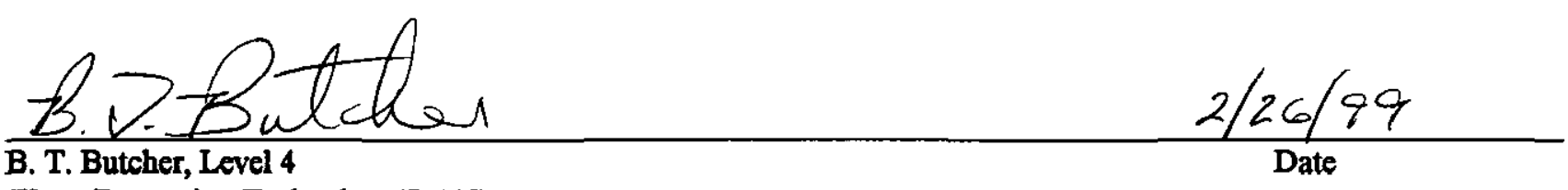

Waste Processing Technology/SRTC

Ulthren

W. E. Stevens, Level 3

Waste Processing Technology/SRTC

Gestate on ULTamosaitis

W. L. Tamosaitis, Lever / 3 Waste Processing TechnologyłSRTC

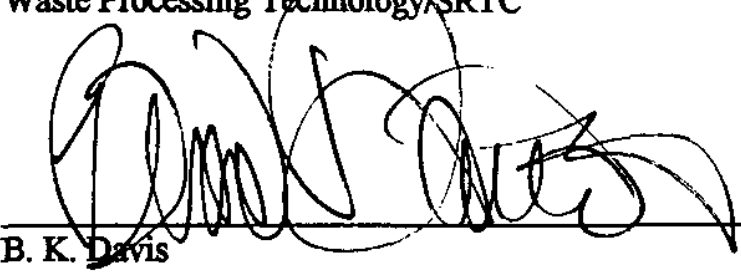

Environmental Engineering/WSRC
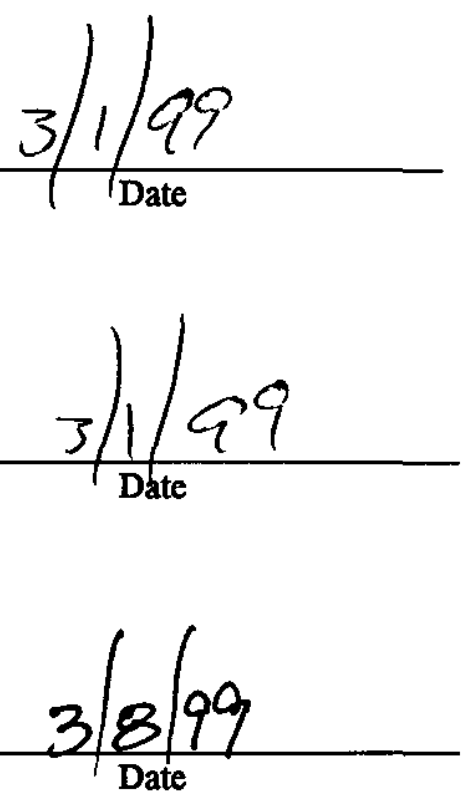


\section{TABLE OF CONTENTS}

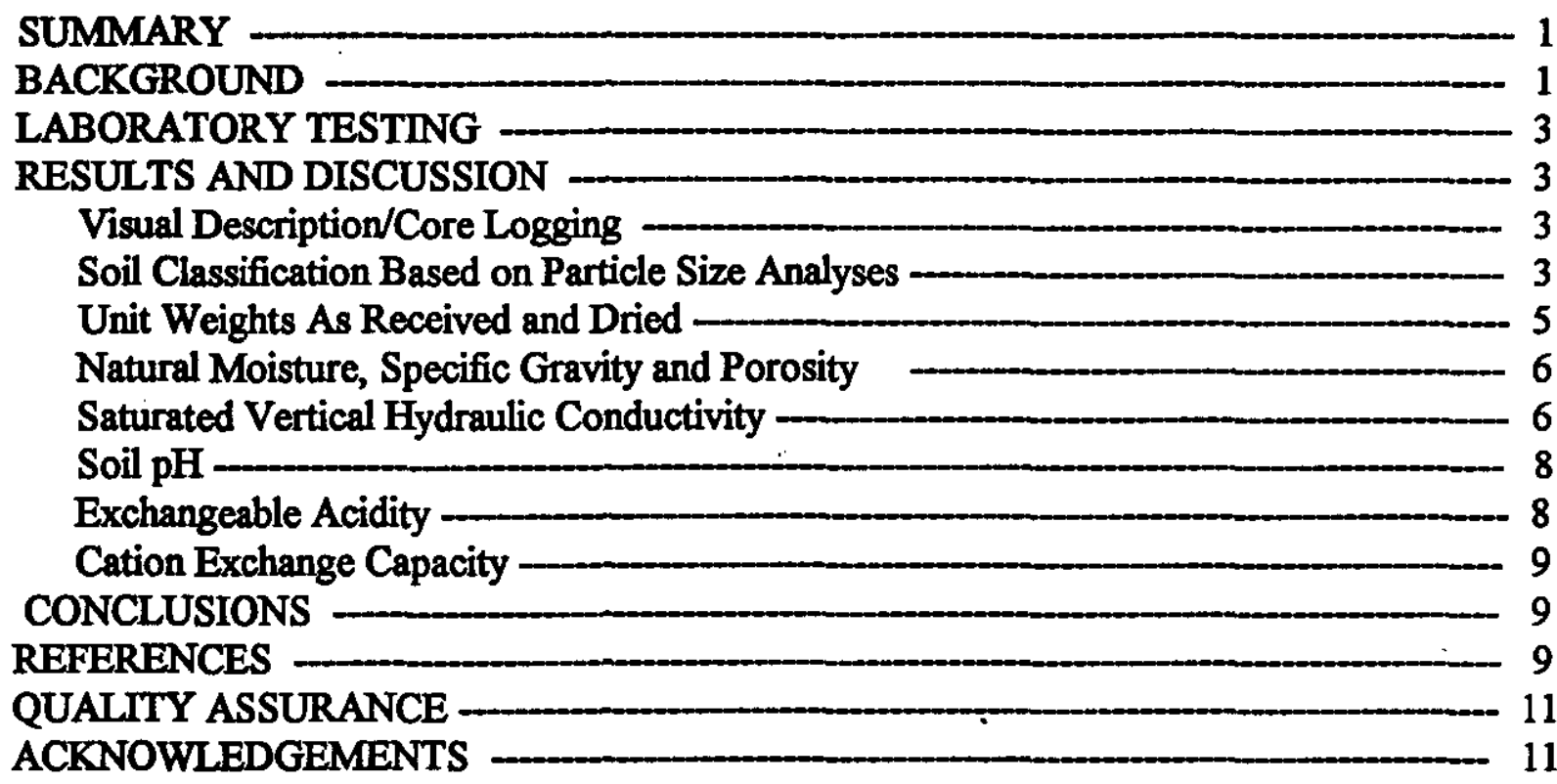

APPENDICIES

APPENDIX 1. HRB Shelby Tube Sample Descriptions _-___ A-1

APPENDIX 2. Particle Size Analyses (Sieve and Hydrometer), Soil Classifications Specific Gravity Data Sheets _________- A-2

APPENDIX 3. Saturated Vertical Hydraulic Conductivity Data Sheets -_.___._- A-3

APPENDIX 4. Exchangeable Acidity Data Sheets ﹎.._- A-4

APPENDIX 5. Sodium Concentrations for Cation Exchange Capacity Calculations - A-5

APPENDIX 6. Chain of Custody for the HRB Shelby Tube samples _ A-6

\section{TABLES}

Table 1. Soil Classification Based on Particle Size of the HRB Shelby Tube Samples -_- 4

Table 2. Unit Weights of As Received HRB Shelby Tube Samples - 5

Table 3. Unit Weights of Dried HRB Shelby Tube Samples ___ 5

Table 4. Natural Moisture Content, Specific Gravity and Porosity of HRB Samples -_- 6

Table 5. Vertical Hydraulic Conductivities ( $k_{\text {etaratod }}$ ) of HRB Shelby Tube Samples-_-- 7

Table 6. Comparison of Water Contents of As Received and Saturated Samples From the HRB Shelby Tubes

Table 7. $\mathrm{pH}$ Values for the HRB Shelby Tube Samples _____________ 8

Table 8. Exchangeable Acidity of the HRB Shelby Tube Samples _- 8

Table 9. Cation Exchange Capacity of the HRB Shelby Tube Samples -..._._. 9

Table 10. Summary of the Geotechnical Properties of the HRB Shelby Tube Samples - 10

Table 11. Summary of the Geochemical Properties of the HRB Shelby Tube Samples _- 10

\section{FIGURES}

Figure 1. Locations of the HRB Shelby Tube Samples Analyzed in This Study -anz 2 


\section{WESTINGHOUSE SAVANNAH RIVER COMPANY SAVANNAH RIVER TECHNOLOGY CENTER}

\section{GEOTECHNICAL ANALYSIS OF FIVE SHELBY TUBE SAMPLES FROM THE H-AREA RETENTION BASIN (U)}

Christine A. Langton

Westinghouse Savannah River Company

Savannah River Technology Center, Aiken, SC 29808

W. L. Mhyre

Raytheon Engineers \& Contractors

Savannah River Site

Aiken, SC 29808

\section{SUMMARY}

Geotechnical and geochemical analyses were performed on five Shelby tube samples collected in the H-Area Retention Basin (HRB) during July and August of 1998. The samples were collected as part of the HRB characterization study. The test results, which are documented in this report, will be used to support the HRB contaminant fate and transport modeling/analysis and to evaluate remedial options. The results will also be used as a base line for future treatability studies.

The geotechnical testing was performed in the SRTC low-level radioactive soils characterization laboratory. WSRC/SRTC and Raytheon personnel conducted the test program. ASTM and EPA test protocols were used. Sample locations are indicated in Figure 1. The physical and chemical properties of the samples are consistent with the soil types, i.e., clayey sands to sandy clay. Details of the soil classifications are provided in Table 1 . Test results are summarized in Tables 2 to 11. Data sheets are provided in the Appendices A-1 to A-6.

\section{BACKGROUND}

Descriptions of the HRB (281-3H) construction and operating history are provided elsewhere. ${ }^{1,2}$

Samples analyzed in this task were collected as part of the 1998 HRB sampling and characterization program which was conducted to support the Resource Conservation and Recovery Act Facility Investigation/Remedial Investigation Work Plan (RFI/RI) for the H-Area Retention Basin (HRB) Operable Unit (OU). Results obtained in this study will be used to support fate and transport analysis, evaluate remedial action objectives, and support human health and ecological risk assessments involved in HRB remediation. They will also be used to support future treatability studies.

During the sampling campaign in 1998, Shelby tube samplers were used to collect undisturbed material from the basin at 3 locations (HRBS-04, -05, and -06) and from three wells (HR3-14C at 
10.0 to 12.0 feet below land surface (ft bls), HR3-15C at 132.0 to $134.0 \mathrm{ft}$ bls., and HR3-16 DL at 6.0 to $8.0 \mathrm{ft}$ bls). Five Shelby tubes, which were identified by Environmental Restoration personnel for this series of tests, were relocated to SRTC, 773-A on 12-28-98. They included well samples, HRB-14C, HR3-15C and HR3-16DL, and samples collected from the basin bottom, HRBS-25-01, and HRBS-27-01. The samples were sealed and transported to building 772-7B for temporary refrigerated storage. Storage in SRTC was under ambient conditions.

L. A. Bagwell, SGS, provided a correlation between the sample locations and the Shelby tube labels. This information is provided below:

\begin{tabular}{lccccc}
\hline SHEILBY TUBE I.D. & HR3-15C & HR3-16DL & HRBS-25-01 & HRBS-27-01 & HRB-14C \\
\hline Corresponding well or bore hole & Well & Well & Hole & Hole & . Well \\
& HR3-15C & HR3-16DL & HRBS-05 & HRBS-06 & HR3-14C \\
Date Sampled & 5 Aug. 1998 & 30 June 1998 & 23 July 1998 & 27 July 1998 & 10 July 1998 \\
Ground Elevation (ft above mean sea level) & 263.3 & 254.9 & $\sim 263$ & $\sim 263$ & 264.5 \\
Sample Depth (ft below land surface) & $132-134$ & $6-7$ & $0-2.5$ & $0-2.5$ & $8-10$ \\
Sample Elevation (ft above mean sea level) & $129.3-131.3$ & $247.9-248.9$ & $260.5-263$ & $260.5-263$ & $254.5-256.5$ \\
Approximate Core Length (inches) & 12 & 16 & 20 & 15.5 & 26 \\
\hline
\end{tabular}

The locations of these samples are shown in Figure 1.

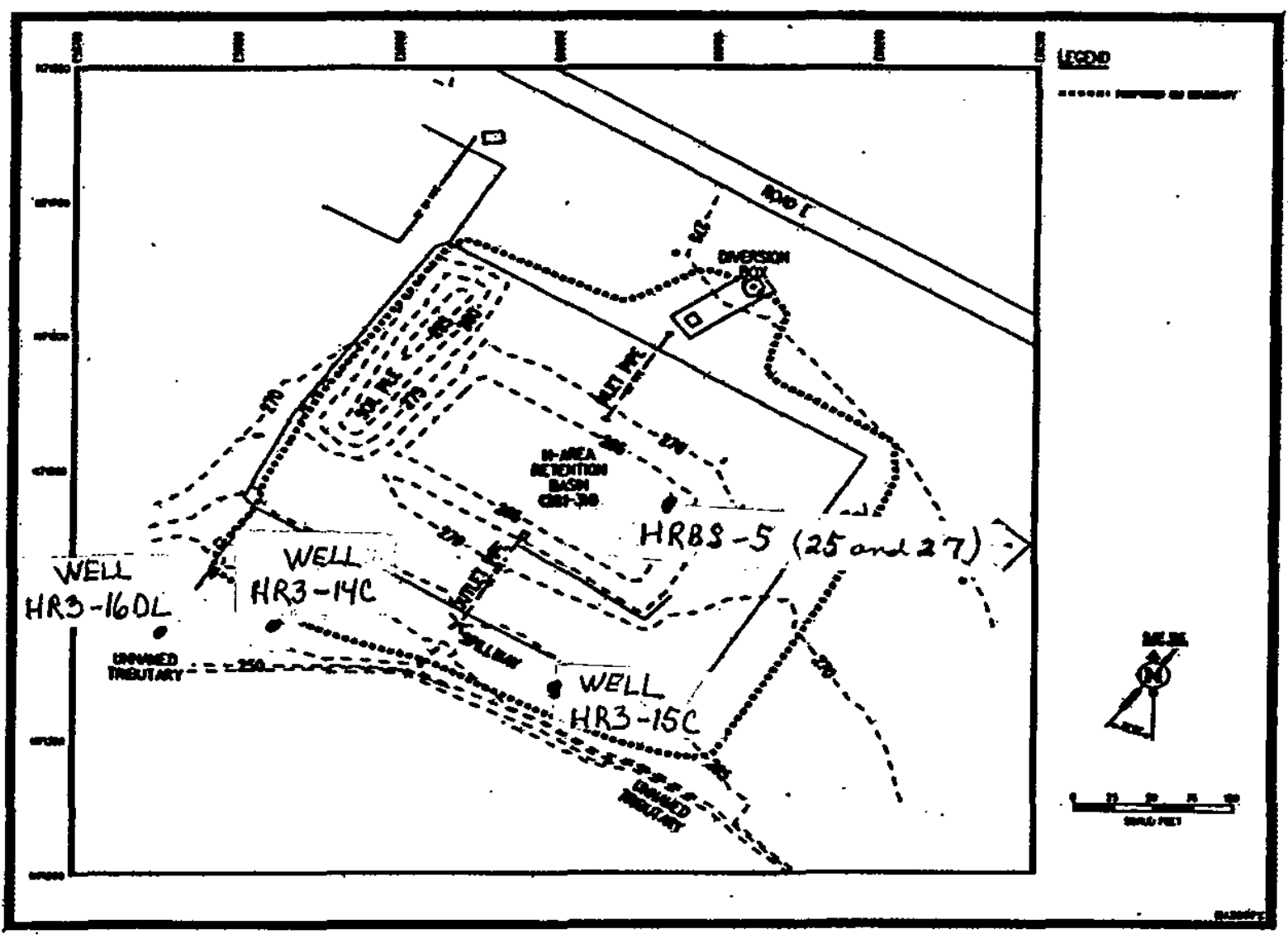

Figure 1. H-Area Retention Basin Sampling Locations 


\section{LABORATORY TESTING}

Geochemcial properties of the soil samples were determined according to the United States Environmental Protection Agency (EPA) SW-846 methods. Physical and hydrological parameters were determined using American Society for Testing and Materials (ASTM) or United States Army Corps of Engineers (COE) procedures, as applicable. The following tests were conducted:

1. Core Logging

2. Particle Size

a. \#200 Sieve Analysis (ASTM D-1140)

b. Sieve Analysis (ASTM D-421)

c. Hydrometer Analysis (ASTM D-422)

3. Unit Weight and Moisture (SRTC Procedure)

4. Natural Moisture (ASTM D-2216)

5. Bulk Density (ASTM D-4531)

6. Specific Gravity ASTM D-854)

7. Porosity (calculation)

8. Falling Head Permeability - Vertical (ASTM D-5084)

9. pH (US EPA)

10. Exchangeable Acidity (US EPA 305.1)

11. Cation Exchange Capacity (US EPA 9081)

\section{RESULTS AND DISCUSSION}

\section{Visual Description/Core Logging}

The descriptions of the soil/sediment samples in the HRB Shelby tubes are given in Appendix A-1. The soils were clayey sands to sandy clays. The descriptions are consistent with the soil classifications based on the particle size data reported below.

\section{Soil Classification Based on Particle Size Analyses}

Particle size data generated by sieve analyses (ASTM D-421 and ASTM D-1140) and hydrometer analyses (ASTM D-422) were used to determine the soil classifications of samples from each of the HRB Shelby tubes. A summary of these results and the soil classifications is presented in Table 1. The Data sheets with the test results are given in Appendix 2.

Slight differences in the visual descriptions and the soil classifications were anticipated because only a small portion (about 3 inches) of the core was selected for the particle size analyses. This material was also judged to be the most representative of the core.

The most consolidated section of the core was selected for the hydraulic conductivity tests since the parameter of interest is related to the ability of the strata to act as a confining layer. Representative material was selected for the other tests. Gravel layers were not intentionally included since larger samples are necessary to accurately evaluate the amount and distribution of the gravel and/or cobbles on the physical properties of these soils. 
Table 1. Soil Classification Based on Particle Size Analyses of the HRB Shelby Tube Samples.

\begin{tabular}{|c|c|c|c|c|c|c|c|c|}
\hline & $\begin{array}{l}\text { Gravel } \\
\text { (wt. \%)* }\end{array}$ & $\begin{array}{l}\text { Coarse } \\
\text { Sand } \\
\text { (wt. \%) }\end{array}$ & $\begin{array}{l}\text { Mediu } \\
\text { Sand } \\
\text { (wt. \%) }\end{array}$ & $\begin{array}{l}\text { Fine } \\
\text { Sand } \\
\text { (wt. \%) }\end{array}$ & $\begin{array}{l}\text { Silt } \\
\text { (wt \% }\end{array}$ & $\begin{array}{l}\text { Clay } \\
\text { (wt.\%) }\end{array}$ & $\begin{array}{l}\text { Colloid } \\
\text { (wt. \%)* }\end{array}$ & Classification*** \\
\hline \multicolumn{9}{|l|}{ Well Samples } \\
\hline HRB-14C & 1 & 1 & 9 & 49 & 3 & 37 & $(<34)$ & Clayey Fine Sand \\
\hline HR3-15C & 8 & 9 & 8 & 52 & 8 & 15 & $(<14)$ & $\begin{array}{l}\text { Clayey Fine to Med } \\
\text { Sand }\end{array}$ \\
\hline HR3-16DL & 0 & 0 & 16 & 60 & 8 & 16 & $(<14)$ & Clayey Fine Sand \\
\hline \multicolumn{9}{|l|}{ Basin Samples } \\
\hline HRBS-25-01 & $\mathbf{0}$ & 2 & 20 & 22 & 6 & 50 & $(<45)$ & $\begin{array}{l}\text { Sandy Clay or } \\
\text { Clayey Fine to } \\
\text { Med. Sand }\end{array}$ \\
\hline HRBS-27-01 & 2 & 7 & 38 & 24 & 6 & 23 & $(<20)$ & Clayey Med. Sand \\
\hline
\end{tabular}

* The gravel and larger cobble size fractions are under represented in this description because the small diameter ( 2 and $5 / 8$ inch diameter) of the Shelby tubes excluded collection of any larger material which may be present in the strata.

* * The colloidal portion of the sample is a subset of the clay fraction.

*** ASTM D-422 provides the following definitions for the various size fractions.

Gravel: Material passing the 3 inch $(7.62 \mathrm{~cm})$ sieve and retained on the No. 4 sieve $(4.75 \mathrm{~mm})$.

Sand: Material passing the No.4 sieve $(4.75 \mathrm{~mm})$ and retained on the No. $200(75 \mathrm{~mm})$ sieve.

a) Coarse sand = Material passing the No.4 $(4.75 \mathrm{~mm})$ sieve and retained on the No.10 $(2.00 \mathrm{~mm})$ sieve.

b) Medium Sand = Material passing the No. $10(2.00 \mathrm{~mm})$ sieve and retained on the No. $40(425 \mu \mathrm{m})$ sieve.

c) Fine sand = Material passing the No. 40 sieve $(425 \mu \mathrm{m})$ and retained on the No. 200 sieve $(75 \mu \mathrm{m})$.

Silt Size: Material 0.074 to $0.005 \mathrm{~mm}$ in diameter.

Clay Size: Material smaller than $0.005 \mathrm{~mm}$.

Colloids: Material smaller than $0.001 \mathrm{~mm}$. 
Unit Weights of the HRB Shelby Tube Samples As Received and Dried

The unit weights of the samples as received and the unit weights of the dry samples are reported in Tables 2 and 3, respectively.

Table 2. Unit Weights of As Received HRB Shelby Tube Samples.

Sample ID $\begin{gathered}\text { Wt. Wet } \\
\text { Soil (grams) }\end{gathered}$
\begin{tabular}{|c|c|c|c|c|c|}
\multicolumn{1}{c}{$\begin{array}{c}\text { Length of } \\
\text { Wet Soil } \\
\text { (inches) }\end{array}$} & \multicolumn{2}{c|}{$\begin{array}{c}\text { Diameter } \\
\text { Soil Core } \\
\text { (inches) }\end{array}$} & $\begin{array}{c}\text { Volume } \\
\text { Sample } \\
\left(\mathrm{ft}^{3}\right)\end{array}$ & $\begin{array}{c}\text { Unit Wt. } \\
\text { Wet } \\
\text { (pcf) }\end{array}$ \\
\begin{tabular}{|c|c|c|c|c|}
\hline Well Samples \\
HRB-14C
\end{tabular} & 782.4 & 3.652 & 2.875 & 0.01 & 125.52 \\
\hline HR3-15C & 654.8 & 2.25 & 2.875 & 0.01 & 170.51 \\
\hline HR3-16DL & 412.5 & 2.18 & 2.875 & 0.01 & 110.86 \\
\hline Basin Samples & & & & & \\
\hline HRBS-25-01 & 672.6 & 3.125 & 2.875 & 0.01 & 126.10 \\
\hline HRBS-27-01 & 518.7 & 2 & 2.875 & 0.01 & 151.95 \\
\hline
\end{tabular}

pcf $=$ pounds per cubic feet

Table 3. Unit Weights of Dried HRB Shelby Tube Samples.

\begin{tabular}{|c|c|c|c|c|c|}
\hline Sample ID & $\begin{array}{l}\text { Wt. Dry } \\
\text { Soil } \\
\text { (grams) }\end{array}$ & $\begin{array}{l}\text { Length of } \\
\text { Dry Soil } \\
\text { (inches) }\end{array}$ & $\begin{array}{l}\text { Diameter } \\
\text { Soil Core } \\
\text { (inches) }\end{array}$ & $\begin{array}{l}\text { Volume } \\
\text { sample } \\
(\mathrm{ft} 3)\end{array}$ & $\begin{array}{c}\text { Unit Wt } \\
\text { dry } \\
\text { (pct) }\end{array}$ \\
\hline \multicolumn{6}{|l|}{ Well Samples } \\
\hline HRB-14C & 625.5 & 3.652 & 2.875 & 0.01 & 100.35 \\
\hline HR3-15C & 460.1 & 2.25 & 2.875 & 0.01 & 119.81 \\
\hline HR3-16DL & 349.5 & 2.18 & 2.875 & 0.01 & 93.93 \\
\hline \multicolumn{6}{|l|}{ Basin Samples } \\
\hline HRBS-25-01 & 545.5 & 3.125 & 2.875 & 0.01 & 102.27 \\
\hline HRBS-27-01 & 463.9 & 2 & 2.875 & 0.01 & 135.90 \\
\hline
\end{tabular}

pcf $=$ pounds per cubic feet 


\section{Natural Moisture, Specific Gravity and Porosity}

Natural moisture was calculated by determining the weight of water in each Shelby tube sample and calculating the moisture content relative to the dry weight of the sample (mass water/mass dry soil X 100). The natural moisture contents and the porosities of the samples are listed in Tables 3 and 4, respectively.

Table 4. Natural Moisture Content, Specific Gravity and Porosity of HRB Shelby Tube Samples.

\begin{tabular}{|c|c|c|c|}
\hline Sample ID & $\begin{array}{c}\text { Natural Moisture } \\
\text { Content } \\
\text { ASTM D-2216 }\end{array}$ & $\begin{array}{c}\text { Specific } \\
\text { Gravity } \\
\text { ASTMD-854 }\end{array}$ & $\begin{array}{c}\text { Porosity } \\
\text { Pore } \\
\text { Fraction }\end{array}$ \\
\hline \multicolumn{4}{|l|}{ Well Samples } \\
\hline HRB-14C & 20.05 & 2.24 & 0.282 \\
\hline HR3-15C & 29.73 & 2.60 & 0.262 \\
\hline HR3-16DL & 15.27 & 2.62 & 0.426 \\
\hline \multicolumn{4}{|l|}{ Basin Samples } \\
\hline HRBS-25-01 & 18.90 & 2.64 & 0.379 \\
\hline HRBS-27-01 & 10.56 & 2.61 & 0.166 \\
\hline
\end{tabular}

\section{Saturated Vertical Hydraulic Conductivity}

Samples for the hydraulic conductivity tests were selected from portions of the core which were considered to be intact. The least fractured, most consolidated, highest clay content portions of the core were selected for the hydraulic conductivity tests because it was assumed that the parameter of interest was the ability of the soil to function as a confining layer. Since the sample length was at least that of the diameter, some of the samples contained gravel (up to $1 / 2$ inch), which was apparent after the samples were removed from the cell, broken up and dried. Minor defects in the core surfaces (up to $3 / 8$ inch deep and of limited surface extent) were patched with similar soil from the core. The samples were oriented in the permeability cell, such that, flow was parallel to the long axis of the core, i.e., vertical conductivities were measured.

Two samples, HR3-15C and HR3-16DL were remolded after no flow was observed after several hours in the cell. Sample HR3-15C had a very high water content and was compacted as the result of the cell and head pressure applied to the sample during testing.

The samples were saturated to $\beta$ values of greater than 0.95 per the ASTM procedure.

Saturation was accomplished in the permeability cell prior to the conductivity measurements.

Results are presented in Table 5. In addition, the final water content after saturation and completion of the hydraulic conductivity test was determined and reported for each sample used for the hydraulic conductivity measurement. This information is listed in Table 6 along with the water content determined on the as received sample. Data sheets are presented in Appendix 4. 
Table 5. Vertical Hydraulic Conductivities (kedereded) of HRB Shelby Tube Samples.

Falling Head Hydraulic Conductivity ASTM D-5084

\begin{tabular}{|c|c|c|c|}
\hline Sample ID & $\begin{array}{c}\text { Run } 1 \\
(\mathrm{~cm} / \mathrm{sec})\end{array}$ & $\begin{array}{c}\text { Run } 2 \\
(\mathrm{~cm} / \mathrm{sec})\end{array}$ & $\begin{array}{l}k_{\text {Ave. }} \\
(\mathrm{cm} / \mathrm{sec})\end{array}$ \\
\hline \multicolumn{4}{|l|}{ Well Samples } \\
\hline HRB-14C & $1.67 \mathrm{E}-04$ & $2.03 \mathrm{E}-04$ & $1.85 \mathrm{E}-04$ \\
\hline HR3-15C & $1.06 \mathrm{E}-06$ & - & $1.06 \mathrm{E}-06$ \\
\hline HR3-16DL & $2.67 \mathrm{E}-05$ & $2.29 \mathrm{E}-05$ & $2.48 \mathrm{E}-05$ \\
\hline \multicolumn{4}{|l|}{ Basin Samples } \\
\hline HRBS-25-01 & $4.02 \mathrm{E}-06$ & - & $4.02 \mathrm{E}-06$ \\
\hline HRBS-27-01 & $1.73 \mathrm{E}-05$ & $1.78 \mathrm{E}-05$ & $1.76 \mathrm{E}-05$ \\
\hline
\end{tabular}

Table 6. Comparison of Water Contents Of As Received and Saturated Samples From the HRB Shelby Tubes.

\begin{tabular}{|c|c|c|}
\multicolumn{2}{c}{$\begin{array}{c}\text { Water Content As } \\
\text { Received } \\
\text { (from Table 2) } \\
\text { (wt. \% of solid) }\end{array}$} & $\begin{array}{c}\text { Water Content After Saturation } \\
\text { (from hydraulic conductivity } \\
\text { data sheets) } \\
\text { (wt. \% of solid) }\end{array}$ \\
\hline Well Samples & & \\
\hline HRB-14C & 20.05 & 25.2 \\
\hline HR3-15C & 29.73 & 32.9 \\
\hline HR3-16DL & 15.27 & 12.0 \\
\hline Basin Samples & & \\
\hline HRBS-25-01 & 18.90 & 29.2 \\
\hline HRBS-27-01 & 10.56 & 17.5 \\
\hline
\end{tabular}




\section{Soil pH}

The $\mathrm{pH}$ of the soil is a measurement of the $\mathrm{H}^{+}$ion concentration in the pore fluid, which is in equilibrium with the soil, i.e., $\mathrm{pH}=\log \left(1 / \mathrm{C}_{\mathrm{H}+}\right)$. The measurement determines the degree of acidity or alkalinity of the soil materials suspended in water. Deionized water was used to obtain these values per the EPA test method 9045A. Results for the HRB Shelby tube samples are listed in Table 7.

Table 7. ph Values for the HRB Shelby Tube Samples.

\begin{tabular}{|c|c|c|c|}
\hline Sample ID & $\begin{array}{c}\mathrm{pH} \\
\text { sample } 1 \\
\end{array}$ & $\begin{array}{c}\mathrm{pH} \\
\text { sample 2 }\end{array}$ & $\begin{array}{c}\mathrm{pH} \\
\text { Average }\end{array}$ \\
\hline \multicolumn{4}{|l|}{ Well Samples } \\
\hline HRB-14C & 8.7 & 8.2 & 8.45 \\
\hline HR3-15C & 8 & 7.28 & 7.64 \\
\hline HR3-16DL & 5.9 & 5.14 & 5.52 \\
\hline \multicolumn{4}{|l|}{ Basin Samples } \\
\hline HRBS-25-01 & 8.7 & 7.88 & 8.29 \\
\hline HRBS-27-01 & 5.7 & 4.75 & 5.22 \\
\hline
\end{tabular}

\section{Exchangeable Acidity}

Exchangeable acidities of the HRB Shelby tube samples were determined according to EPA Method 305.1. This test measures the mineral acidity of the sample plus the acidity resulting from oxidation and hydrolysis of polyvalent cations, such as, salts of iron and aluminum. Results are summarized in Table 8, and the data sheets are presented in Appendix 4.

Table 8. Exchangeable Acidity of the HRB Shelby Tube Samples.

Sample ID
\begin{tabular}{|c|c|c|c|}
\hline Well Samples & $\begin{array}{c}\text { Acidity (ueq/L) } \\
\text { Sample A }\end{array}$ & $\begin{array}{c}\text { Acidity (ueq/L) } \\
\text { Sample B }\end{array}$ & $\begin{array}{c}\text { Acidity (ueq/L) } \\
\text { Average }\end{array}$ \\
\hline HRB-14C & & & 130.4 \\
\hline HR3-15C & 90.3 & 170.5 & 427.3 \\
\hline HR3-16DL & 360.1 & 494.5 & 246.1 \\
\hline Basin Samples & 251.4 & 240.8 & \\
\hline HRBS-25-01 & & & 160.5 \\
\hline HRBS-27-01 & 170.0 & 180.1 & 123.1 \\
\hline
\end{tabular}




\section{Cation Erchange Capacity}

The cation exchange capacity (CEC) is a measure of the negative charges carried by the soil particles, organic matter and sesquioxides. US EPA Method 9081 was used for these determinations. Results are summarized in Table 9 and analytical data for sodium concentrations of tests solutions are presented in Appendix 5.

Table 9. Cation Exchange Capacity of the HRB Shelby Tube Samples.

$\operatorname{CEC}\left(\mathrm{C}_{\text {moloo }} \mathrm{kg}\right.$ soil $) \mathrm{CEC}$ ( $\mathrm{C}_{\text {moloo }} \mathrm{kg}$ soil $) \mathrm{CEC}\left(\mathrm{C}_{\text {moloo }} / \mathrm{kg}\right.$ soil $)$

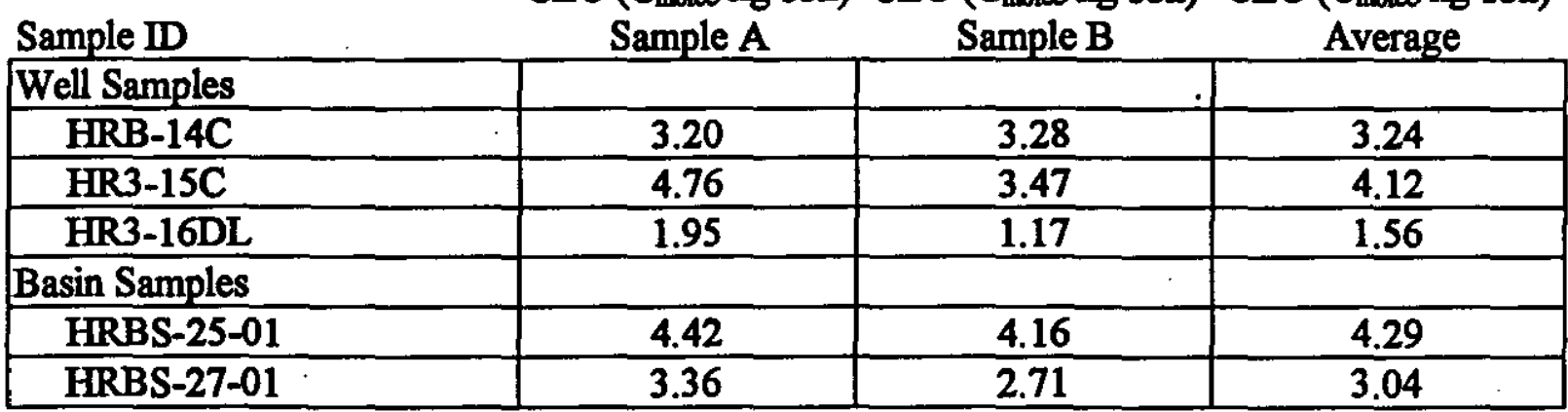

\section{CONCLUSIONS}

The HRB Shelby tube samples analyzed in this study are clayey sands. One sample from the bottom of the basin, HRBS-25-01, is sandy clay. Geotechnical and geochemical test results obtained in the test program are consistent with the soil types and are summarized in Tables 10 and 11, respectively. Data sheets are included in the Appendices A-1 to A-6.

\section{REFERENCES}

1. WSRC-RP-97-122, Rev. 0, March 1997, “ASCAD"m Combined Feasibility Study Proposed Plan Document for the H-Area Retention Basin (281-3H) (U)," Westinghouse Savannah River Company, Aiken, SC.

2. WSRC-RP-98-00125, Rev. 0, March 1998, “281-3H Retention Basin Treatability Study Work Plan (U)," Westinghouse Savannah River Company, Aiken, SC.

3. WSRC-RP-99-121, Rev. 0., January 21, 1999, "Task Technical Plan for Geotechnical Analysis of Five H-Area Retention Basin (HRB) Shelby Tube Samples (U)," Westinghouse Savannah River Company, Aiken, SC.

4. WSRC-RP-99-122, Rev. 0., January 21,1999, “Task Quality Assurance Plan for Geotechnical Analysis of Five H-Area Retention Basin (HRB) Shelby Tube Samples (U)," Westinghouse Savannah River Company, Aiken, SC. 
Table 10. Summary of the Geotechnical Properties of the HRB Shelby Tube Samples.

\begin{tabular}{|c|c|c|c|c|c|c|c|c|c|}
\hline Sample ID & $\begin{array}{c}\text { Ground } \\
\text { Elevation } \\
\text { Ft above } \\
\text { MSL } \\
\end{array}$ & $\begin{array}{c}\text { Sample } \\
\text { Depth } \\
\text { Ft below } \\
\text { land surface }\end{array}$ & $\begin{array}{c}\text { Sample } \\
\text { Elevation } \\
\text { Ft above MSL }\end{array}$ & $\begin{array}{c}\text { Specific } \\
\text { Gravity } \\
\text { ASTM } \\
\text { D-854 } \\
\end{array}$ & $\begin{array}{c}\text { Porosity } \\
\text { Pore } \\
\text { Fraction }\end{array}$ & $\begin{array}{c}\text { Unit Wt } \\
\text { as } \\
\text { received } \\
\text { (pcf) }\end{array}$ & $\begin{array}{c}\text { Unit Wt } \\
\text { dry } \\
\text { (pen) }\end{array}$ & $\begin{array}{c}\text { Natural } \\
\text { Moisture } \\
\text { \% H2O } \\
\text { ASTM } \\
\text { D-2216 } \\
\end{array}$ & $\begin{array}{c}\text { Vertical } \\
\text { Hydraulic } \\
\text { Conductivity } \\
\text { K ave. } \\
\text { (cm/sec) } \\
\end{array}$ \\
\hline \multicolumn{10}{|l|}{ Well Samples } \\
\hline HRB-14C & 264.5 & 8 to 10 & 254.5 to 256.5 & 2.24 & 0.282 & 125.52 & 100.35 & 20.05 & $1.85 \mathrm{E}-04$ \\
\hline HR3-15C & 263.3 & 132 to 134 & 129.3 to 131.3 & 2.6 & 0.262 & 170.51 & 119.81 & 29.73 & \\
\hline HR3-16DL & 254.9 & 6 to 7 & 247.9 to 248.9 & 2.62 & 0.426 & 110.86 & 93.93 & 15.27 & $2.48 \mathrm{E}-05$ \\
\hline \multicolumn{10}{|l|}{ Basin Samples } \\
\hline HRBS-25-01 & -263 & 0 to 2.5 & 260.5 to 263 & 2.64 & 0.379 & 126.10 & 102.27 & 18.90 & $4.02 \mathrm{E}-06$ \\
\hline HRBS-27-01 & $\sim 263$ & 0 to 2.5 & 260.5 to 263 & 2.61 & 0.166 & 151.95 & 135.90 & 10.56 & $1.76 \mathrm{E}-05$ \\
\hline
\end{tabular}

Table 11. Summary of the Geochemical Properties of the HRB Shelby Tube Samples.

\begin{tabular}{|c|c|c|c|}
\hline Sample ID & pH (ave.) & $\begin{array}{l}\text { Exchangeable } \\
\text { Acidity (ave.) }\end{array}$ & $\begin{array}{l}\text { Cation Exchange } \\
\text { Capacity (ave.) }\end{array}$ \\
\hline \multicolumn{4}{|l|}{ Well Samples } \\
\hline HRB-14C & 8.45 & 130.4 & 3.24 \\
\hline HR3-15C & 7.64 & 427.1 & 4.12 \\
\hline HR3-16DL & 5.52 & 246.1 & 1.56 \\
\hline \multicolumn{4}{|l|}{ Basin samples } \\
\hline HRBS-25-01 & 8.29 & 160.5 & 4.29 \\
\hline HRBS-27-01 & 5.22 & 123.1 & 3.04 \\
\hline
\end{tabular}




\section{QUALITY ASSURANCE}

Testing was conducted in accordance with ASTM standard practices and SRS procedures. Results are recorded in Laboratory Notebook WSRC-NB-98-00204. The Task Technical Plan and Task Quality Assurance Plan for this effort are documented in WSRC-RP-99-00122 and WSRC-RP-99-00121, respectively. The Chain of Custody documentation for the Shelby Tube Samples is provided in Appendix 6.

\section{ACKNOWLEDGEMENTS}

Wyman Pope Jr. and Clyde N. Shramek, Raytheon Engineers \& Constructors, performed the geotechnical testing. Frances Wakefield and Cathey Coffey performed the geochemical testing. Cecil Woodard and Lynda Wingard opened the Shelby tubes and extracted the samples. 


\section{APPENDIX 1.}

HRB Shelby Tube Sample Descriptions 


\section{Visual Descriptions of the HRB Shelby Tube Samples}

\section{HRB-14C}

Approximately 26 inches of core was recovered from the Shelby tube. The upper 7 inches was disturbed and contained about 60 volume \% large (up to 1.5 inches) quartzite gravel plus sand, silt and clay. The gravel is subangular, hard and dense. This section of core is mottled yellow/red/white.

The lower 19 inches is a silty clayey sand and contained no gravel. A few of the largest particles were less than 0.5 inches. The structure of this portion of the core is uniform and the color is mottled yellow/red/white.

\section{HR3-15C}

Approximately 12 inches of core was recovered from this Shelby tube. A few pieces of quartzite gravel were recovered from the top of the sample. The first 7 inches consisted of an organic rich silty sand which was grayish brown in color, mottled, and contained black charcoal particles (up to 3/8 inch), soft white agglomerates of white clay and clear quartz sand, light gray, dense quartzite (up to $3 / 8$ inch).

The next 2 inches was a sandy silt which was similar to the material directly above it except this layer did not contain the carbon and the quartzite gravel was larger (up to 0.5 inches).

The bottom 3 inches of this core was very wet fine silty sand. It is greenish yellow and is not cohesive. This layer contains no gravel.

\section{HR3-16DL}

Approximately 16 inches of core was recovered from the Shelby tube. The upper 13 inches consists of wet mottled gray brown silty sand. It contains a small amount of light gray, dense, subangular quartzite gravel up to 1.5 inches in size. This section of core also contains a few root or twig fragments.

The bottom 3 inches of this core consists of wet, yellowish silty sand with orange mottling.

\section{HRBS-25-01}

Approximately 20 inches of core was recovered from the Shelby tube. Several pieces of quartzite gravel were present at the very top of the tube sample.

The remaining sample is a clayey, silty sand containing 5-10 volume \% hard, dense light gray quartzite gravel up to 1.5 inches in size plus soft aggregates (less than 1 inch in size) of clear quartz sand. The quartz sand aggregates break/crumble very easily. The core is mottled red/yellow/orange and tends to fracture along the red mottling. Some layers have more sand than the others. The core fractured along the red (weathered) zones both perpendicular to and diagonal to the long axis of the core. 
WSRC-TR-99-00057

February 8,1999

Page Al-3

HRBS-27-01

Approximately 20 inches of core was recovered from the shelby tube. Black organic rich liquid was observed above the top plug in the tube. About 3 inches of sand and gravel coated with black organic material was recovered just below the plug. This material was not sampled.

The next 5 inches of core contain fine clayey silty sand without gravel. It is mottled. This section is similar to the bottom 5 inches of this core except the sand is finer.

The next 4 inches of core consisted of a clayey, silty sand which contained about 20 volume $\%$ of the dense quartzite gravel and also about 20 volume $\%$ of the soft clear quartz sand agglomerates in a white clay matrix. The color of this core is mottled yellow/red/white.

The next 2 inches consist of a few large quartzite gravel. This material was unconsolidated after removing it from the tube.

The bottom 5 inches of this core consisted of calyey, silty sand containing and soft clear quartz sand agglomerates up to 1.5 inches in size. 


\section{HRB Shelby Tube Samples}

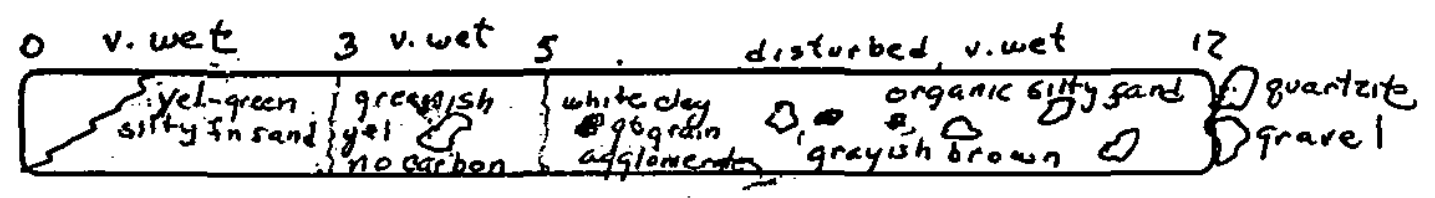

Bottom

HRB3-15C 12 inches

Top
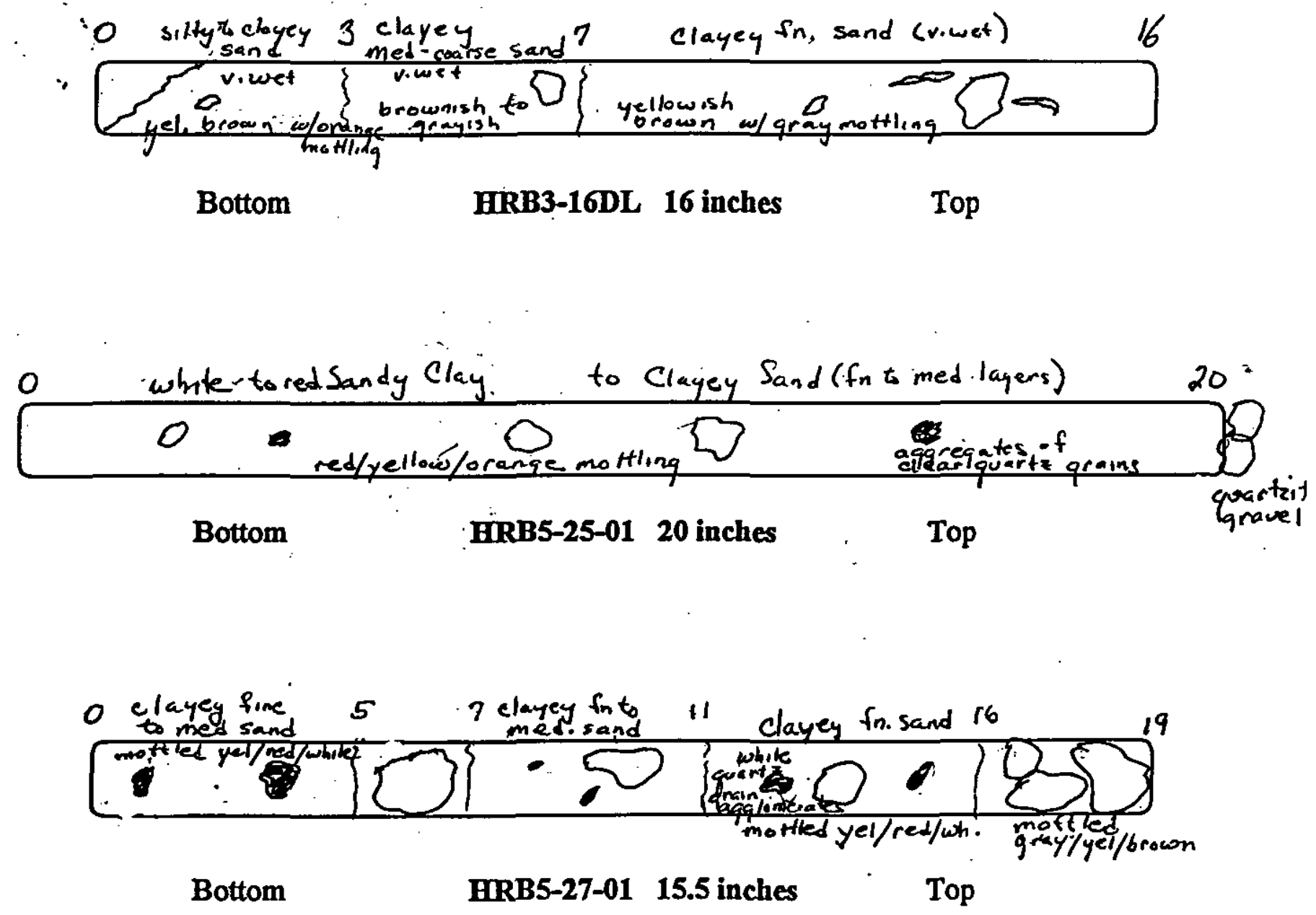

0 sandy clay to clayey fn. sand 19 sandy dayey gravel 26 mottled yel/red/white 
Sample: HR3-14C Date: 1-21-99 Technician: C.Largton + B. Mhyne

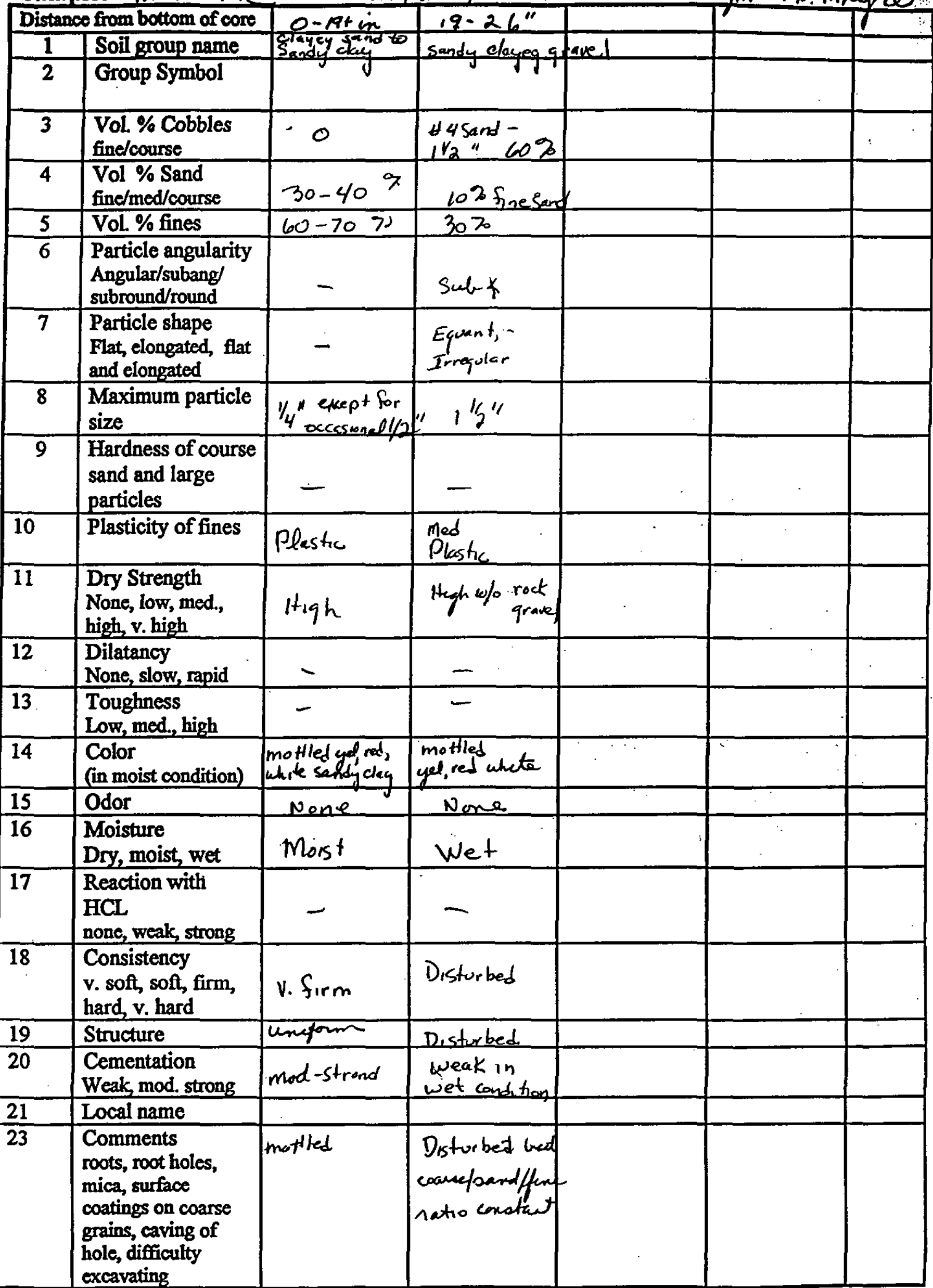




\begin{tabular}{|c|c|c|c|c|c|c|}
\hline \multicolumn{2}{|c|}{ Sample: HR3-15C } & Date: & $1-21.99 \mathrm{Ted}$ & hnician: C.L & nstintB.M & \\
\hline Distan & from bottom of core & $0-3$ inches & $3-5$ & $5-12$ & $12+$ & \\
\hline 1 & Soil group name ff & silty sand & & organic silty & Gravel & \\
\hline 2 & Group Symbol & & & sand & 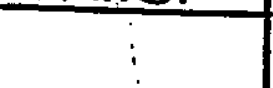 & \\
\hline 3 & $\begin{array}{l}\text { Vol. \% Cobbles } \\
\text { fine/course }\end{array}$ & 0 & $20 \%$ & 257 & $100 \%$ & \\
\hline 4 & $\begin{array}{l}\text { Vol \% Sand } \\
\text { fine/med/course }\end{array}$ & $90-100$ & $\approx 5 \%$ & $65 \%$ & - & \\
\hline 5 & Vol. \% fines & sift ?1092 & 10.572 & 57 & - & \\
\hline 6 & $\begin{array}{l}\text { Particle angularity } \\
\text { Angular/subang/ } \\
\text { subround/round }\end{array}$ & - & $\begin{array}{l}\text { Sub angular } \\
\text { to sub roonded }\end{array}$ & & & \\
\hline 7 & $\begin{array}{l}\text { Particle shape } \\
\text { Flat, elongated, flat } \\
\text { and elongated }\end{array}$ & - & irregular & flat to ieregula & & \\
\hline 8 & $\begin{array}{l}\text { Maximum particle } \\
\text { size }\end{array}$ & - & $<1 / 2.1$ & $3 / 8 "$ & & \\
\hline 9 & $\begin{array}{l}\text { Hardness of course } \\
\text { sand and large } \\
\text { particles }\end{array}$ & - & $\begin{array}{l}\text { Quartzito } \\
\text { hard }\end{array}$ & $\begin{array}{l}\text { Cuartzite } \\
\text { hard }\end{array}$ & $\begin{array}{l}\text { Quarteite } \\
\text { hard }\end{array}$ & \\
\hline 10 & Plasticity of fines & Not Plastic & same & Same & NAmes & \\
\hline$\overline{11}$ & $\begin{array}{l}\text { Dry Strength } \\
\text { None, low, med, } \\
\text { high, v. high } \\
\end{array}$ & $10 \omega$ & 10\% & low & NA & \\
\hline 12 & $\begin{array}{l}\text { Dilatancy } \\
\text { None, slow, rapid }\end{array}$ & - & - & - & - & $:$ \\
\hline 13 & $\begin{array}{l}\text { Toughness } \\
\text { Low, med, high }\end{array}$ & - & - & - & - & \\
\hline 14 & $\begin{array}{l}\text { Color } \\
\text { (in moist condition) }\end{array}$ & 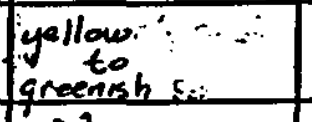 & $\begin{array}{l}\text { greenish } \\
\text { yollow }\end{array}$ & $\begin{array}{l}\text { Same bu } t \\
\text { contains black } \\
\text { pacticles soo it }\end{array}$ & & \\
\hline 15 & Odor & None & None, & None & $\therefore$ & que \\
\hline 16 & $\begin{array}{l}\text { Moisture } \\
\text { Dry, moist, wet }\end{array}$ & Satinaled & v. wet & v. weit & $N A$. & \\
\hline 17 & $\begin{array}{l}\text { Reaction with } \\
\text { HCL } \\
\text { none, weak, strong }\end{array}$ & - & - & - & - & \\
\hline 8 & $\begin{array}{l}\text { Consistency } \\
\text { v. soft, sof, firm, } \\
\text { hard, v. hard }\end{array}$ & soft & soft & soft & $N A$ & \\
\hline 19 & Structure & uniform fingt & same & Distoribed & NA & \\
\hline 0 & $\begin{array}{l}\text { Cementation } \\
\text { Weak, mod. strong }\end{array}$ & not cokesive & & 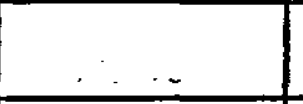 & & \\
\hline 1 & Local name & $=$ & & & & \\
\hline 3 & $\begin{array}{l}\text { Comments } \\
\text { roots, root holes, } \\
\text { mica, surface } \\
\text { coatings on coarse } \\
\text { grains, caving of } \\
\text { hole, difficulty. } \\
\text { excavating }\end{array}$ & $\begin{array}{l}\text { bottom of } \\
\text { shel by tule } \\
\text { sampled in } \\
\text { satoraled fn. } \\
\text { sand v. Ioses }\end{array}$ & - & $\begin{array}{l}\text { bleck p particles } \\
\text { are charcoal. } \\
\text { sample = disturlt } \\
\text { ptructure }\end{array}$ & + & \\
\hline
\end{tabular}


Sample: HR $3 \cdot 16 D L$ Date: $1-21-99$ Technician: C. Langtont 3 . Mhy re

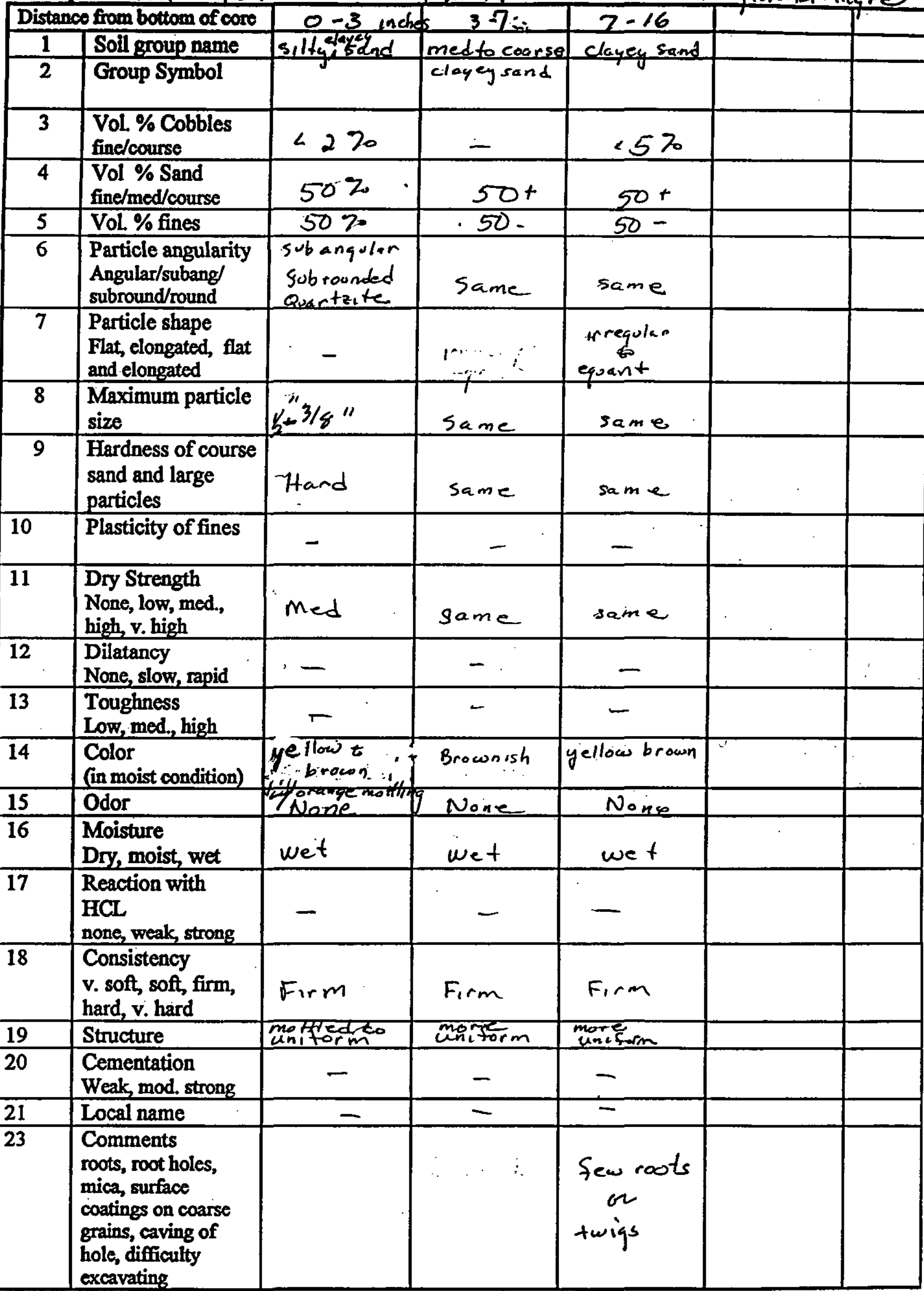




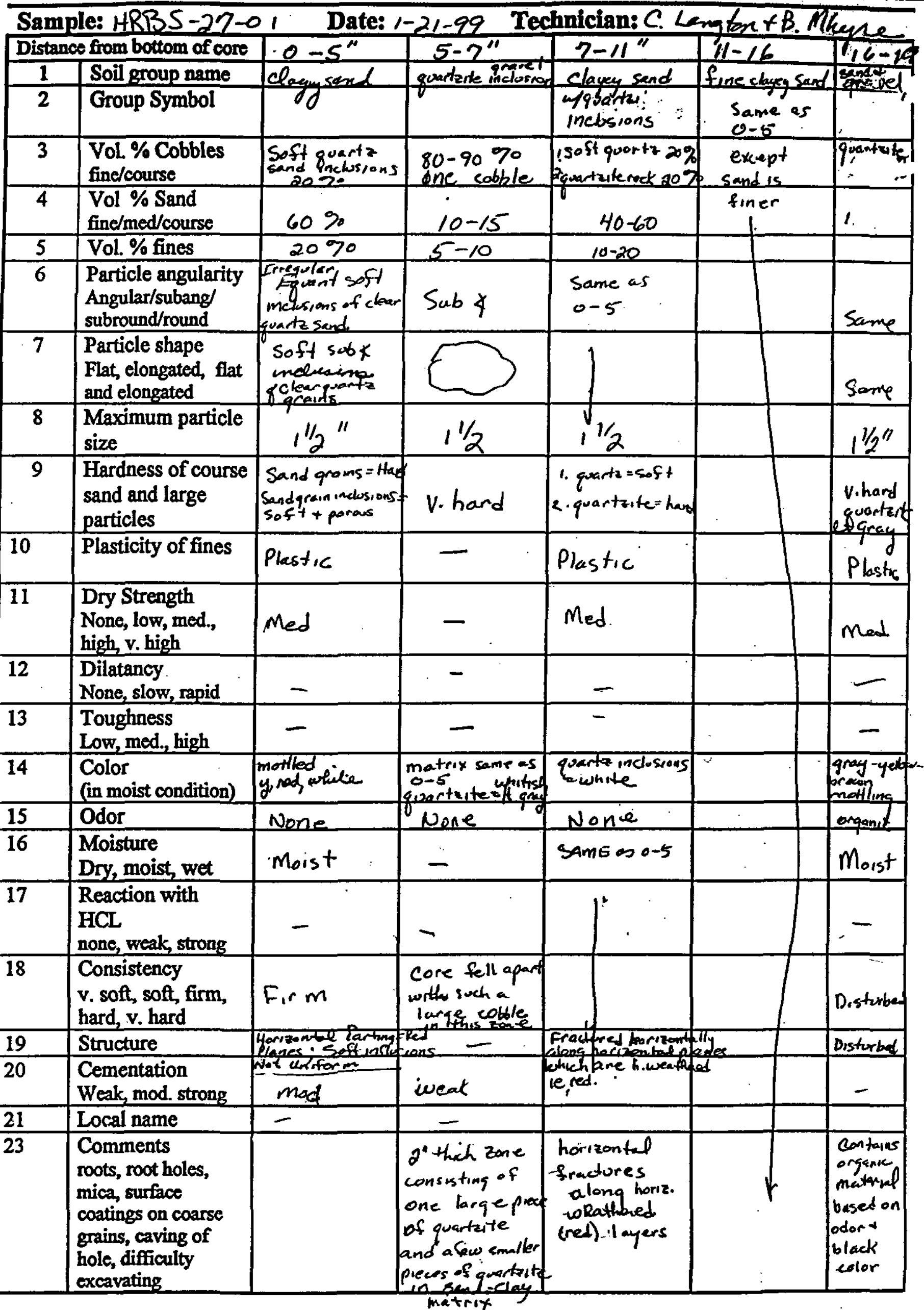




\section{APPENDIX 2.}

Particle Size Analyses (Sieve and Hydrometer),

Soil Classifications

and

Specific Gravity Data Sheet 
Particle-Size Analysis
ASTM D 75- N/A ):
ASTM D 422-(63) $(90):$
ASTM C 136- $(\mathrm{N} / \mathrm{A})$

Report: 99-PER31003R-cad

ProjectwAD \#: PAR 3003B

Work Package No.: _L/A

TwC: N/A Lab HRL $-14 \mathrm{C}$

QCIR No.: N/A

Material Description: CLAYEY FiNJE SANDO

Location: H RETENTIONY BHSIN

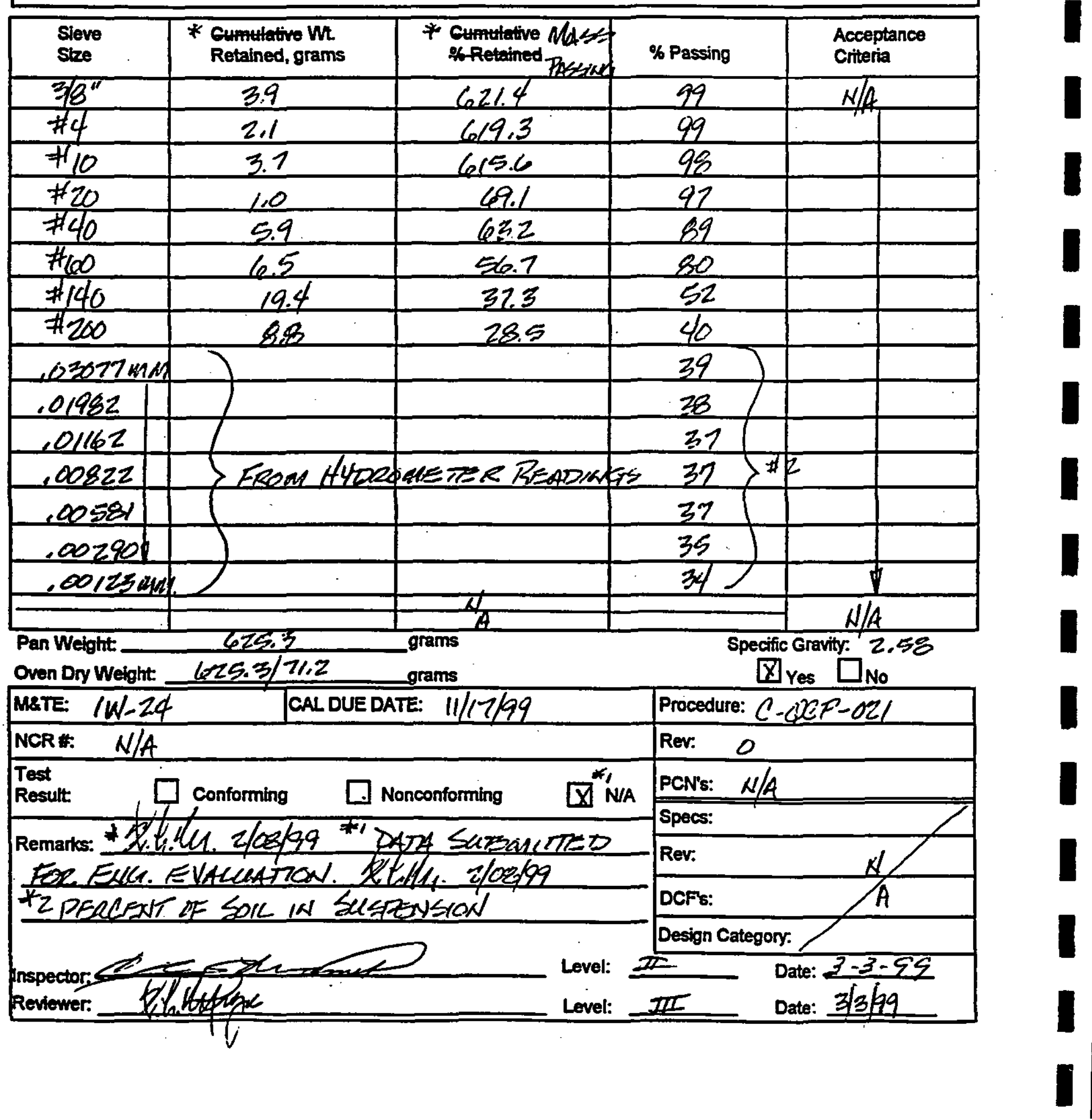



Grain Size Distribution Curve

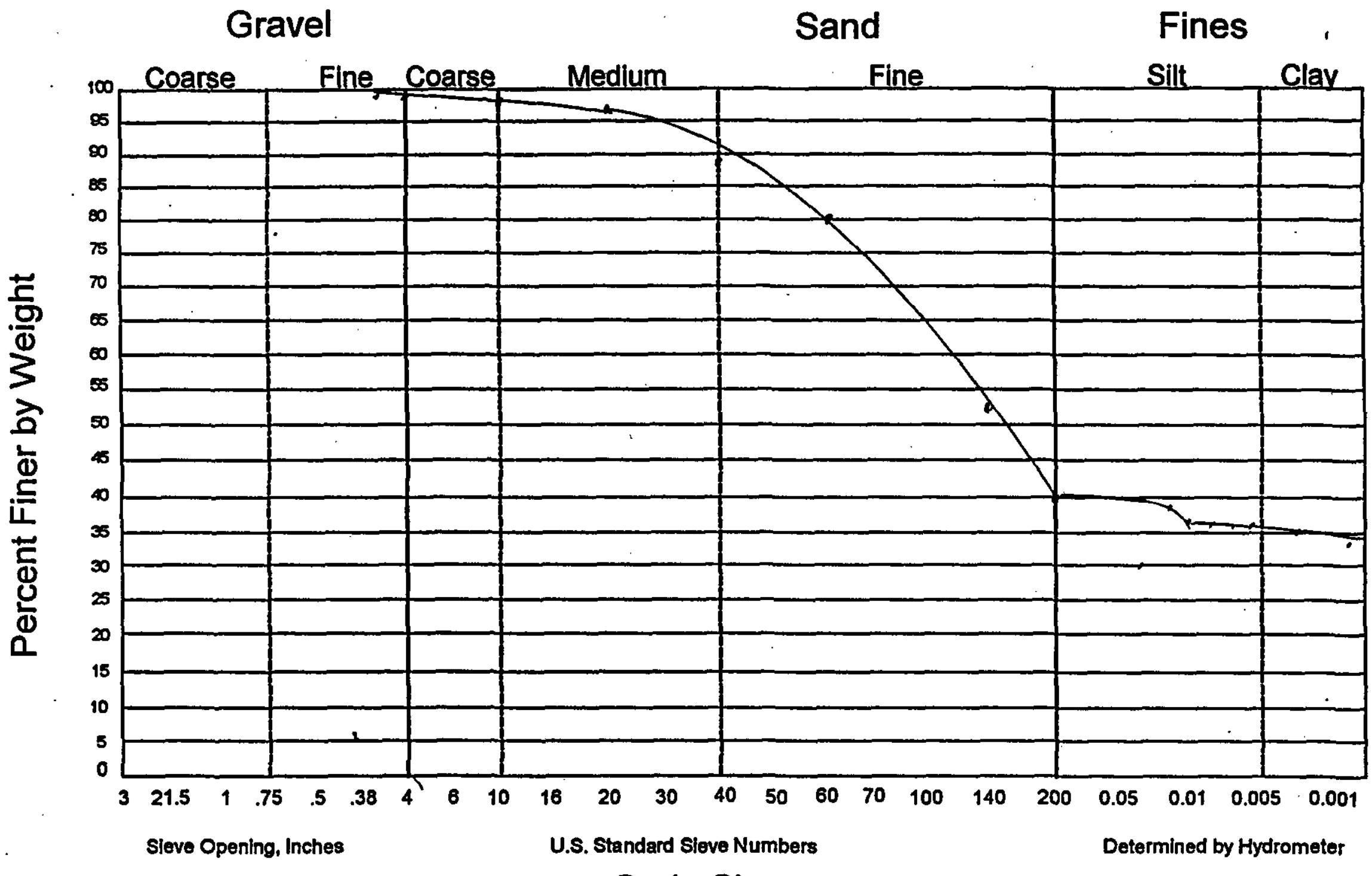

Grain Size

Report\#: 99-PAR31003E-0001 


\section{Particle-Size Analysis}

ASTMD 75- $N / A$ )i ASTM D 422-163)(\$D) $)_{i}^{\prime \prime}:$ ASTMC 136-(N/A)

Report: 99-PAR31003B-c001

ProjectwaD H: PAR31003B

TWC: N/A Lab\#: $14 R 3-15 C$

Material Description:

Location: H RETENMON BHSIN
Work Package No.: N/A

QCIR No.:

N/A

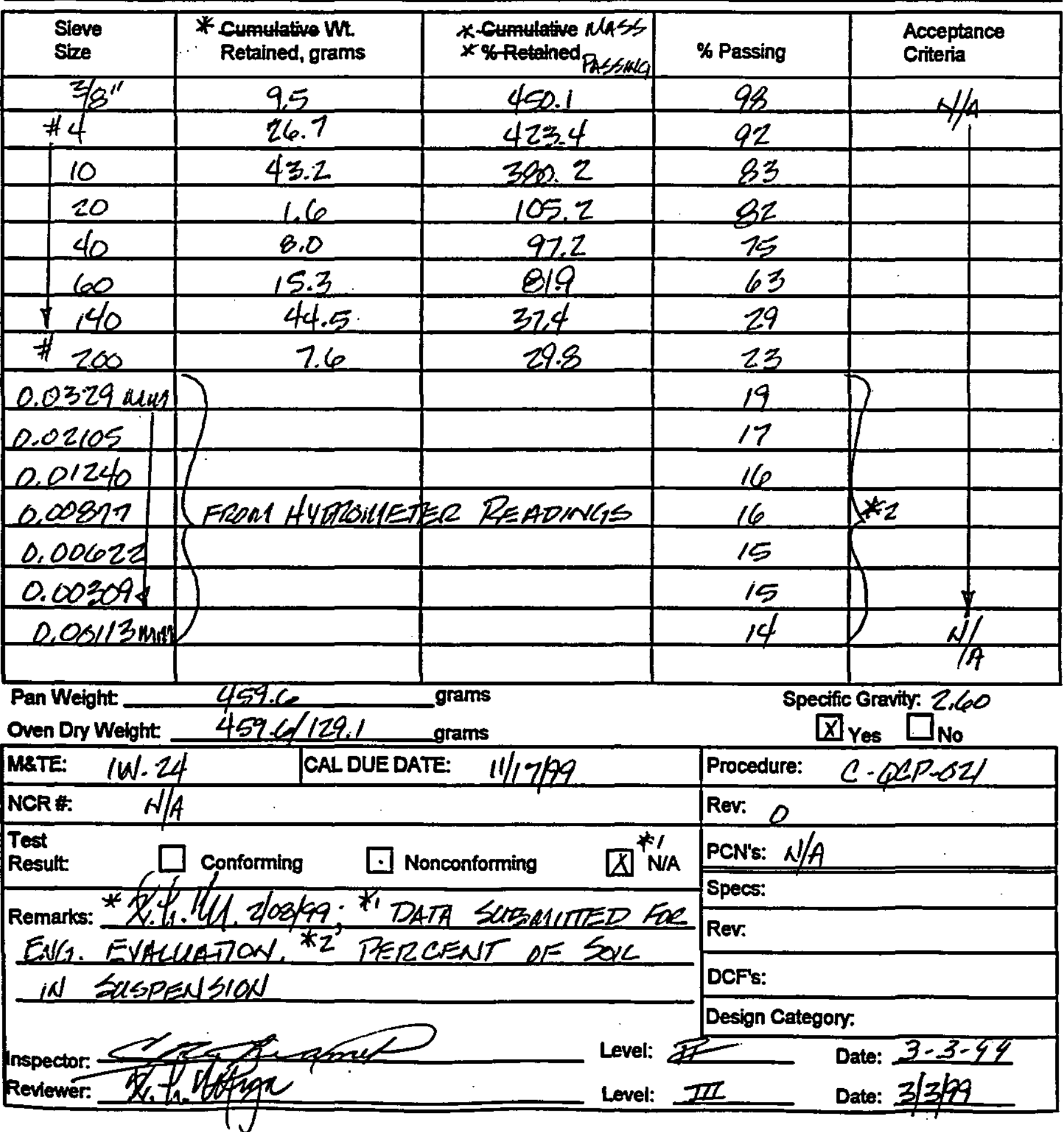




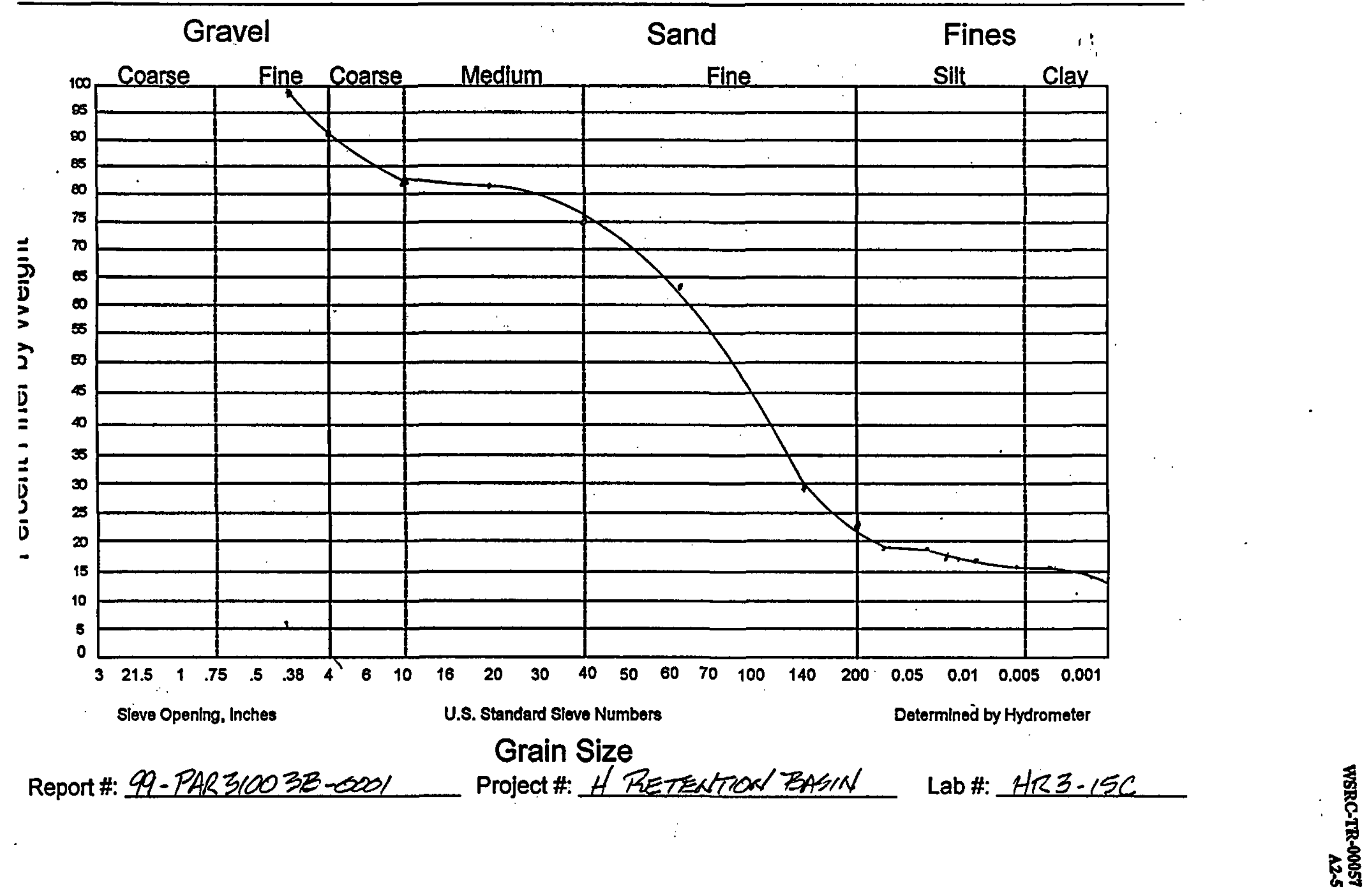


Particle-Size Analysis
ASTMD 75- N/A );
ASTM D 422- 603$)(98)_{i}^{\prime}$
ASTMC 136- N(A )

\begin{tabular}{|c|c|}
\hline Report: 99 -PAK $3 k 0032-0001$ & Work Package No.: \\
\hline ProjectwAD\#: PAR31003B & QCIR No.: \\
\hline
\end{tabular}

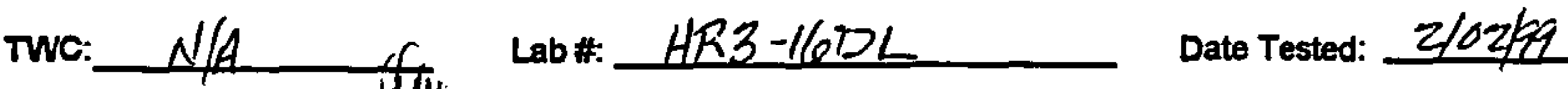

Material Description: NalA CLAYEY FINE SAND

Location: H RENTENITION RASIN

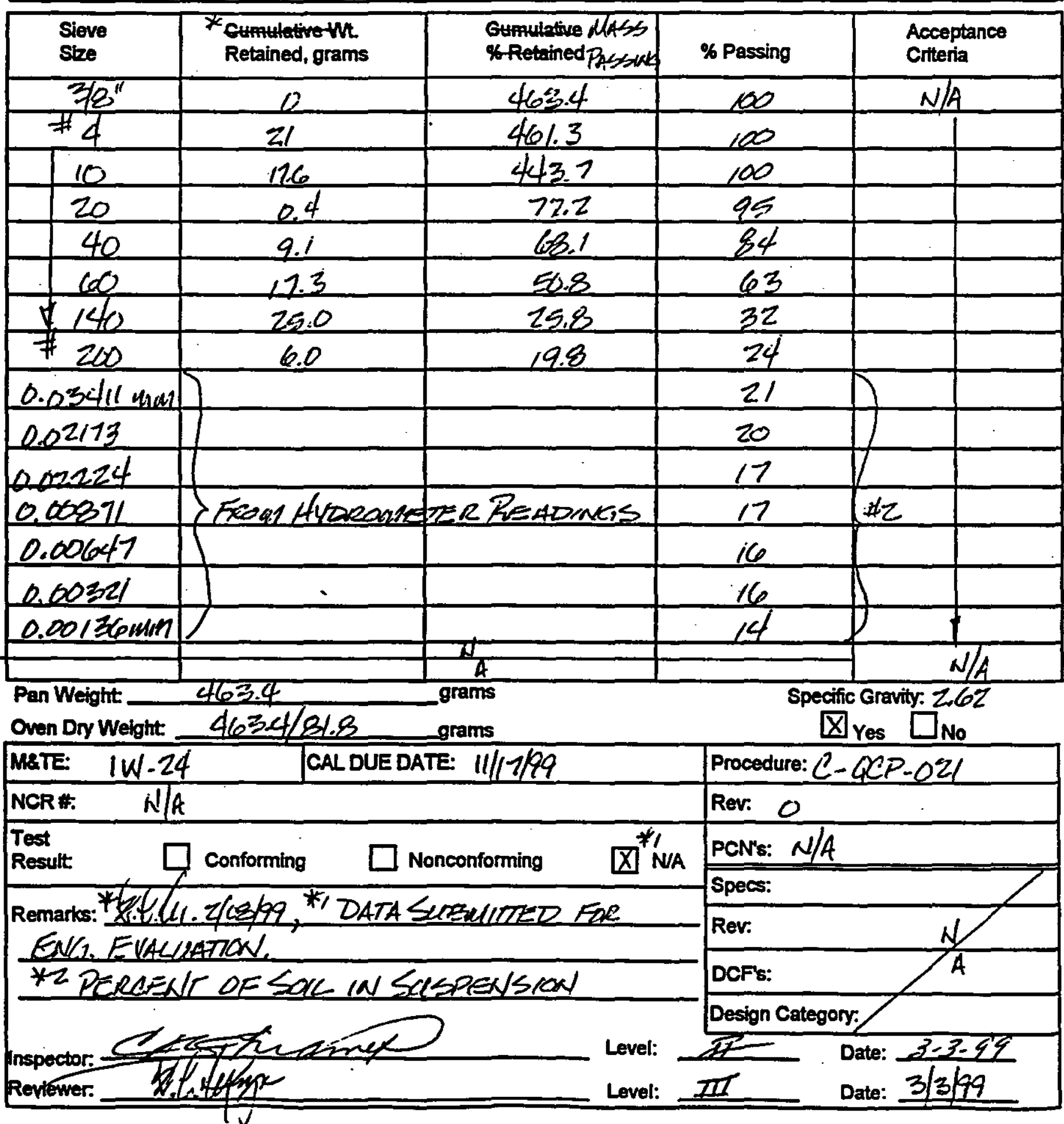




\section{RAYTHEON Engineers \& Constructors Grain Size Distribution Curve}

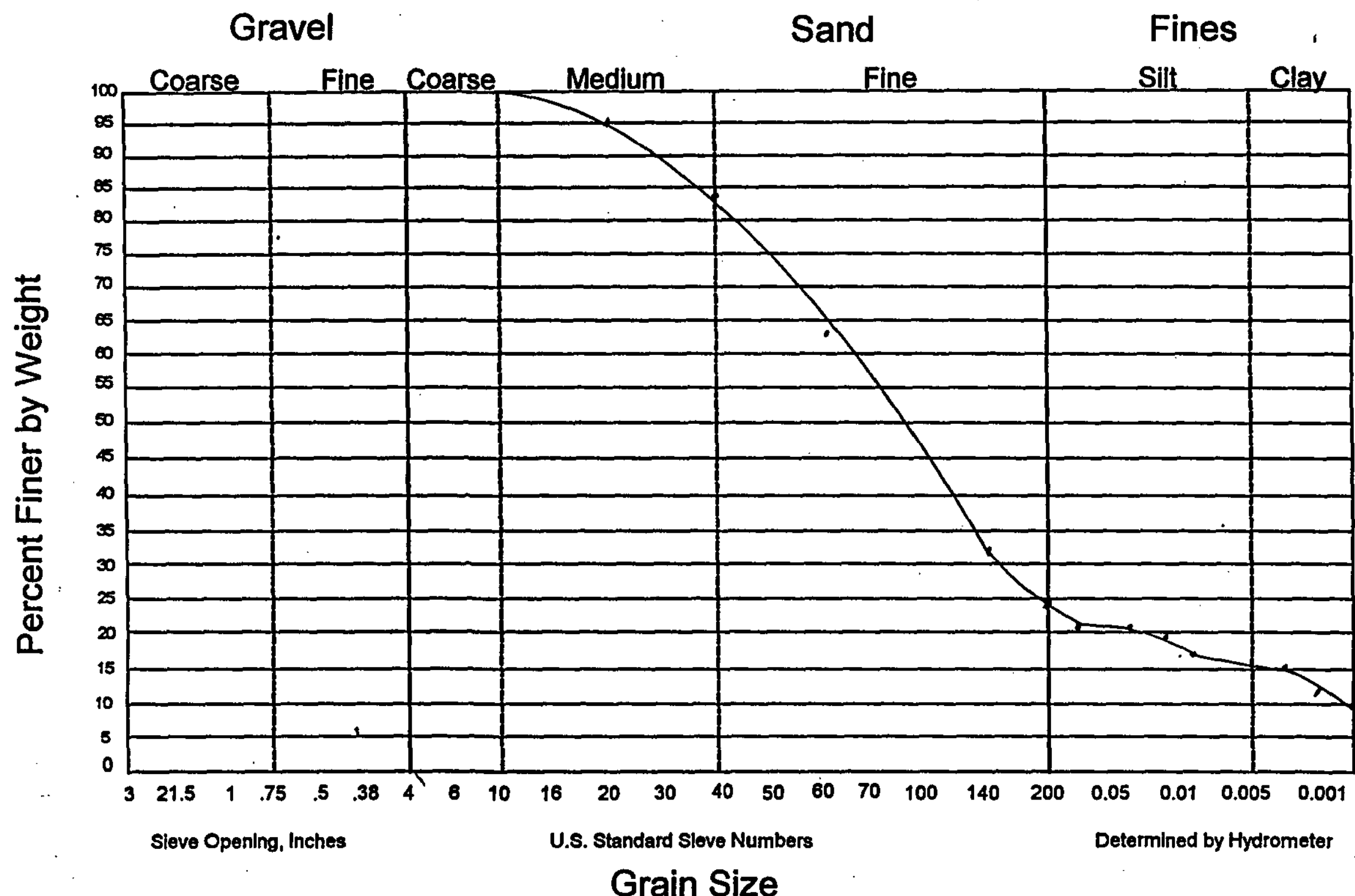

Report\#: 99-PAR31003B-0001

Grain Size

Report: 99 PAh

Project \#: H RETENTIOAL PASIN

Lab \#: $H R 3 \cdot 160 D L$ 
Particle-Size Analysis

ASTM D 75- $N / A)$ ): ASTMD 422-(63)(8) í

ASTMC 136- $N / A)$

Report: 99-PAR310038-0001

ProjectwAD \#. PAR31003B Twc: $\quad N / A$ Lab \# HRR-25-OI

Material Description: CinAYEY FINE SAND Location: H RETENInON BAsold

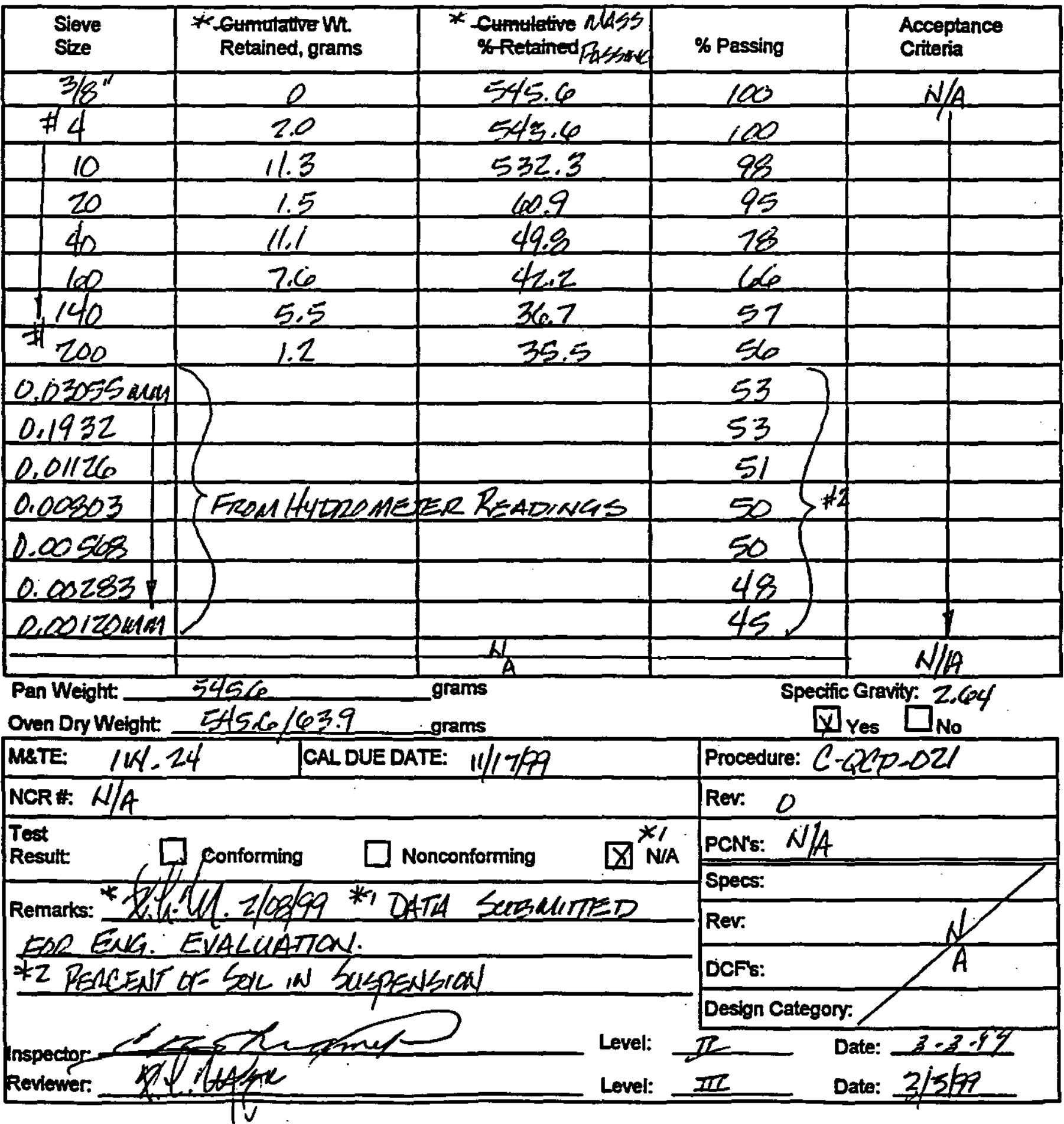




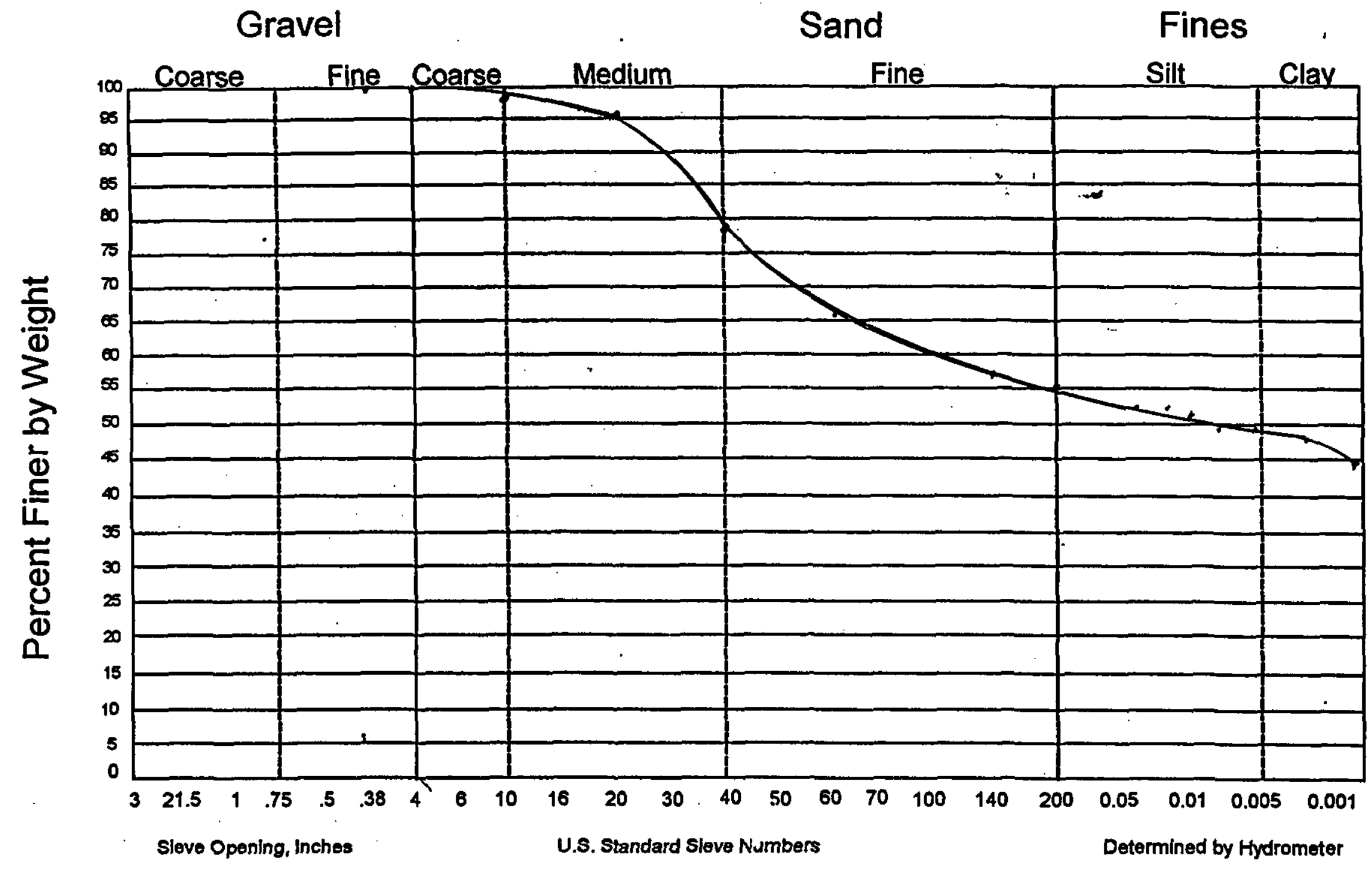

Grain Size

Report \#: 99-FAR310033-0001 Project\#:_H RETENmew Lab \#: HRB, 25.01 


\section{ASTMD75- N/A ); \\ Particle-Size Analysis \\ ASTMC 136- N N/A )}

Report*: 99-PAR 31003B-COOd

Work Package No.: _ N/A

ProjectWAD \#. PAR31003B

QCIR No.: N N/A

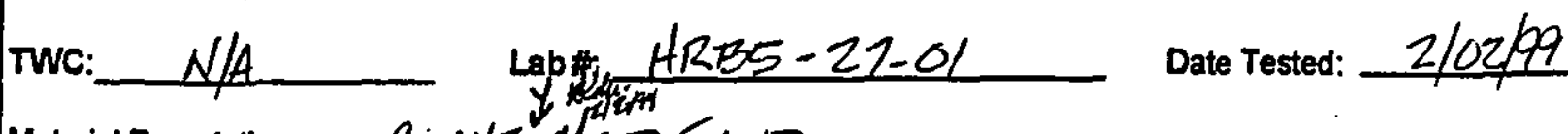

Material Description: CLAUE A OSOSAND

Location: H RETINNTION BASINS

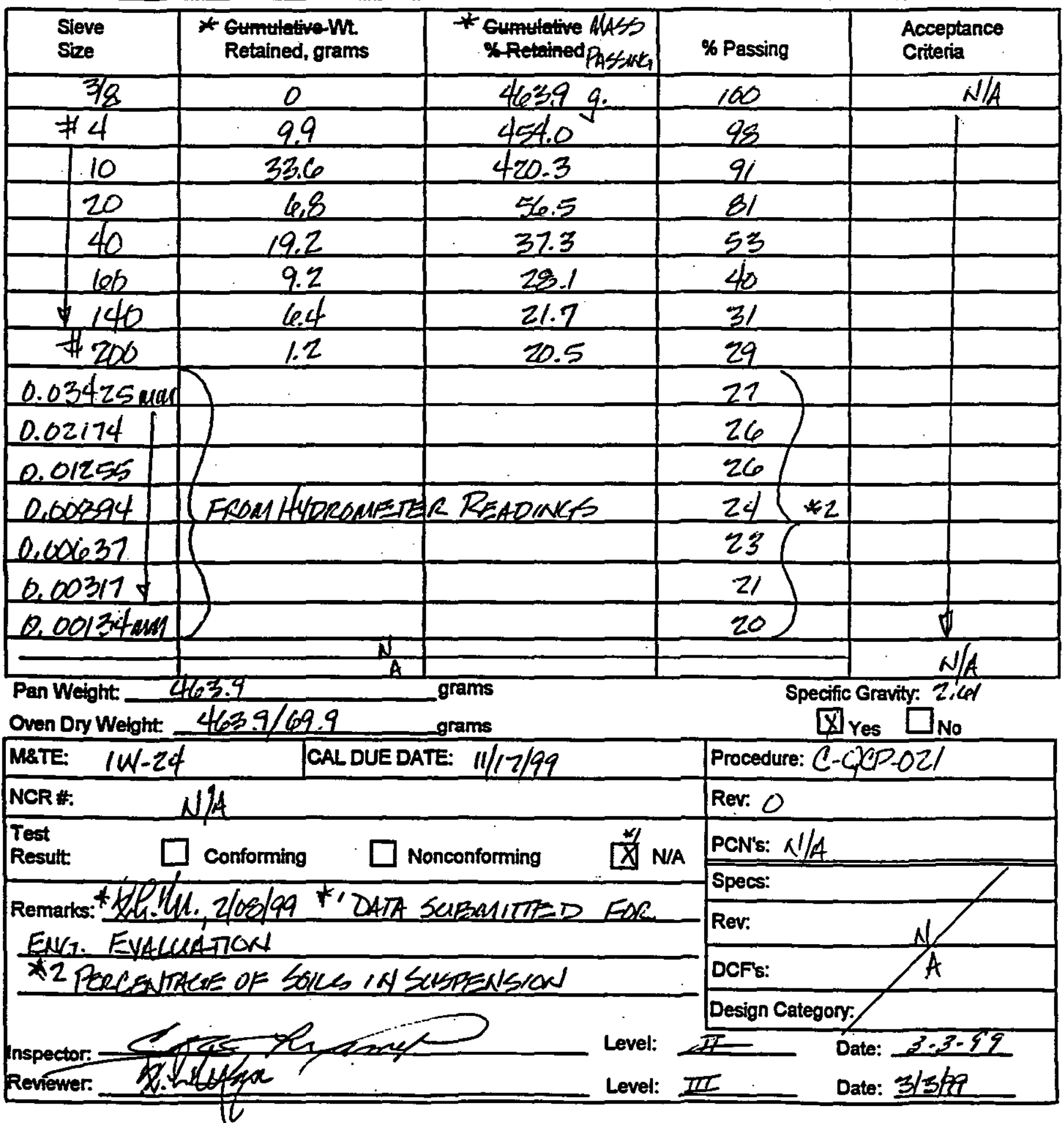


WSRC-TR-00057

A2.11

CFopausamp

RAYTHEON Engineers \& Constructors PAGE 13 of 18 Summary Report of Testing Activities Continuation Sheet

Report Title: H RETENTION BASIN Report No.: 99-PAE31003

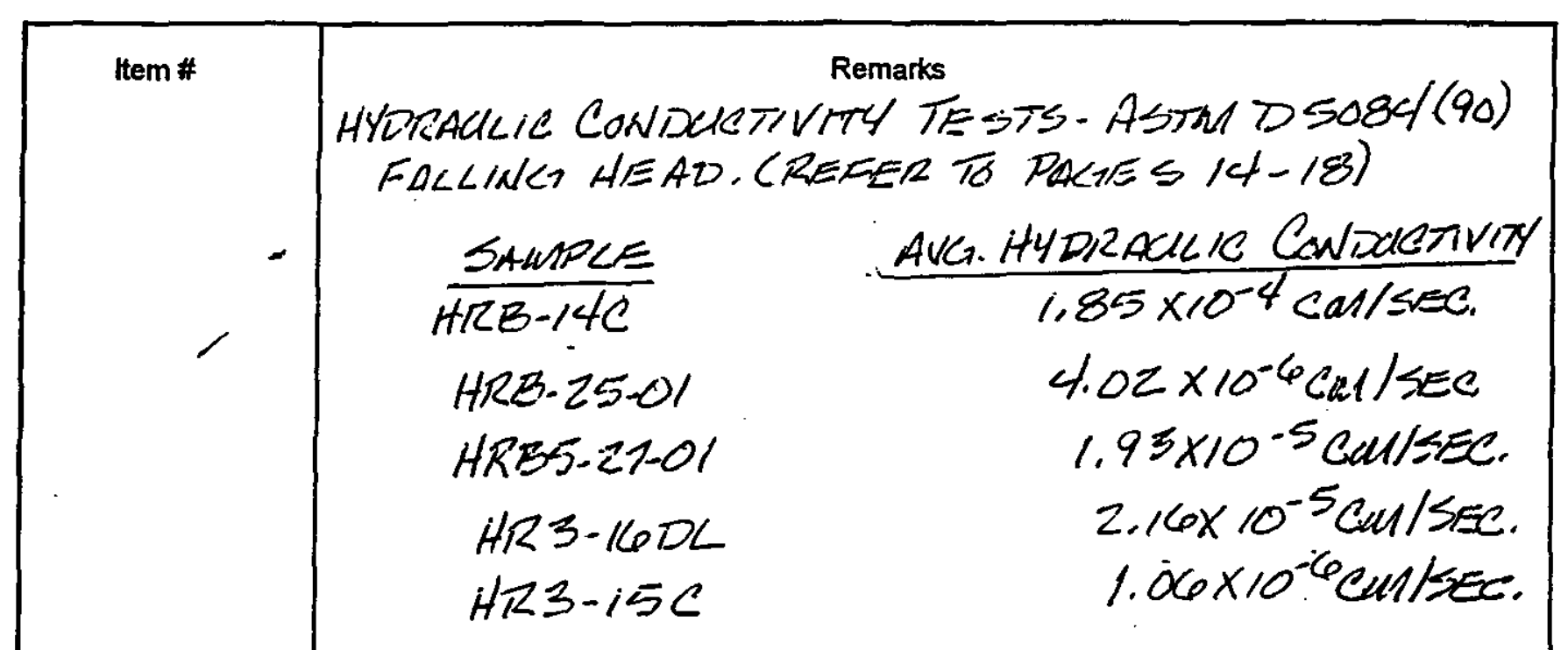

Remarks: 

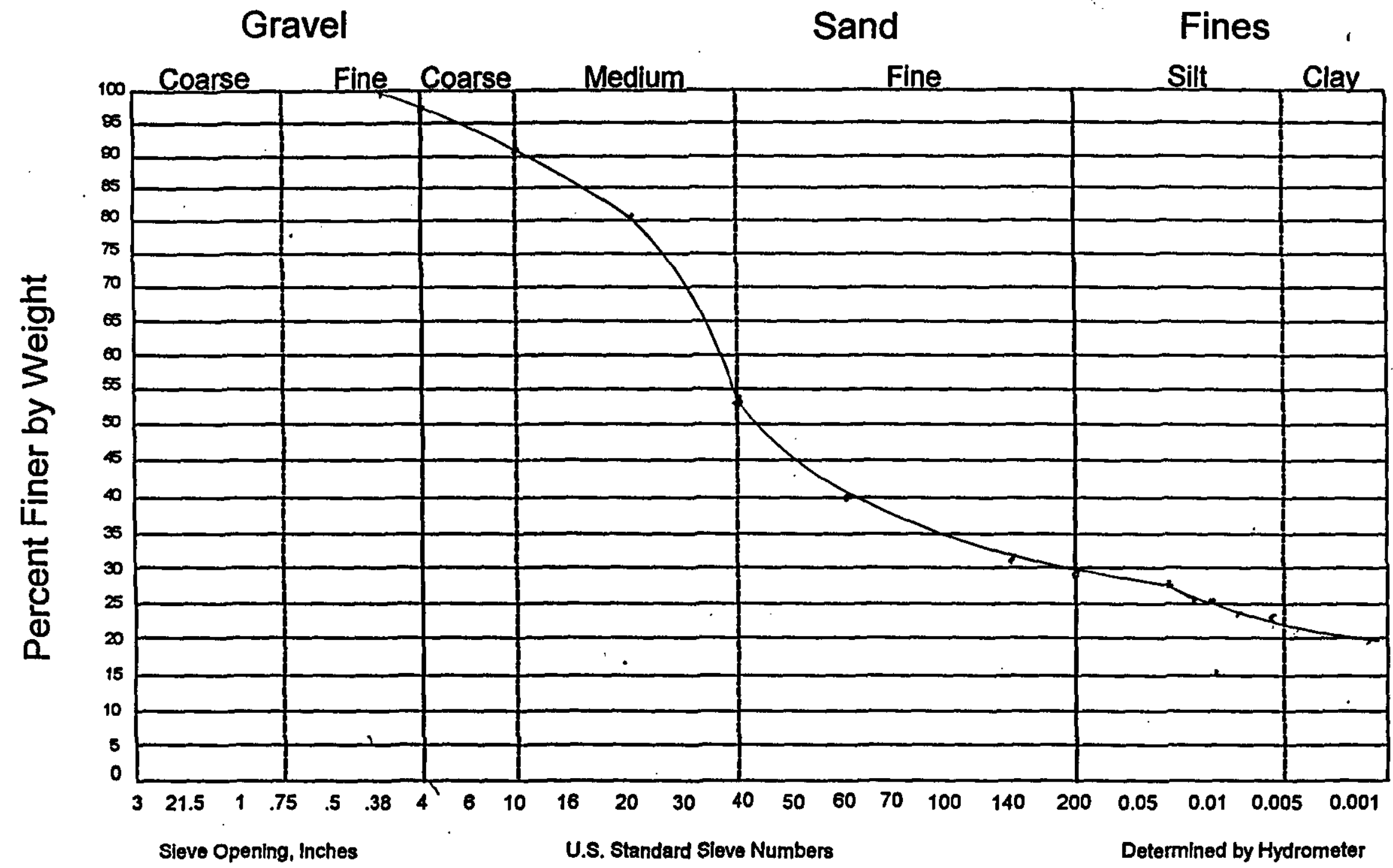

Fines

\section{Grain Size}

Report\#: 49-FAR3i003E-0001 
WSRC-TR-00057

A2-13

QFORUSTFMP
ASR 18-250 (TNO)

RAYTHEON Engineers \& Constructors PAGE 2 of _Summary Report of Testing Activities Continuation Sheet

Report THe: H HREA RETENTION BASCOL

Report No.: 99-PAR34036-0001

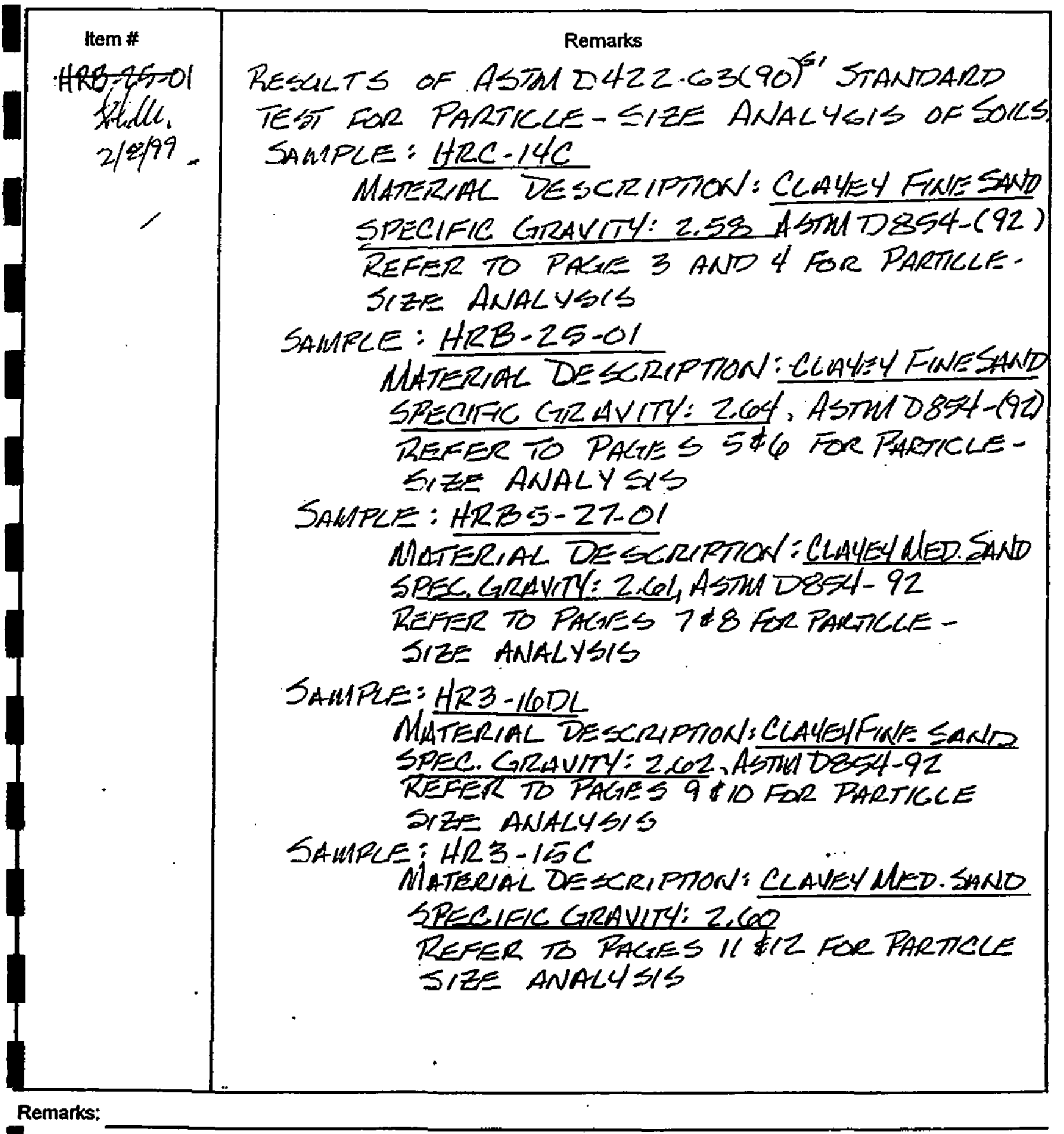




\section{APPENDIX 3.}

Vertical Hydraulic Conductivity Data Sheets for Saturated HRB Shelby Tube Samples 
WSRGTROOHST

ASR 18-332 (7/98)

RAYTHEON Engineers \& Constructors

PALE K 14 OF 18

Hydraulic Conductivity Test

ASTM D 5084-(90)

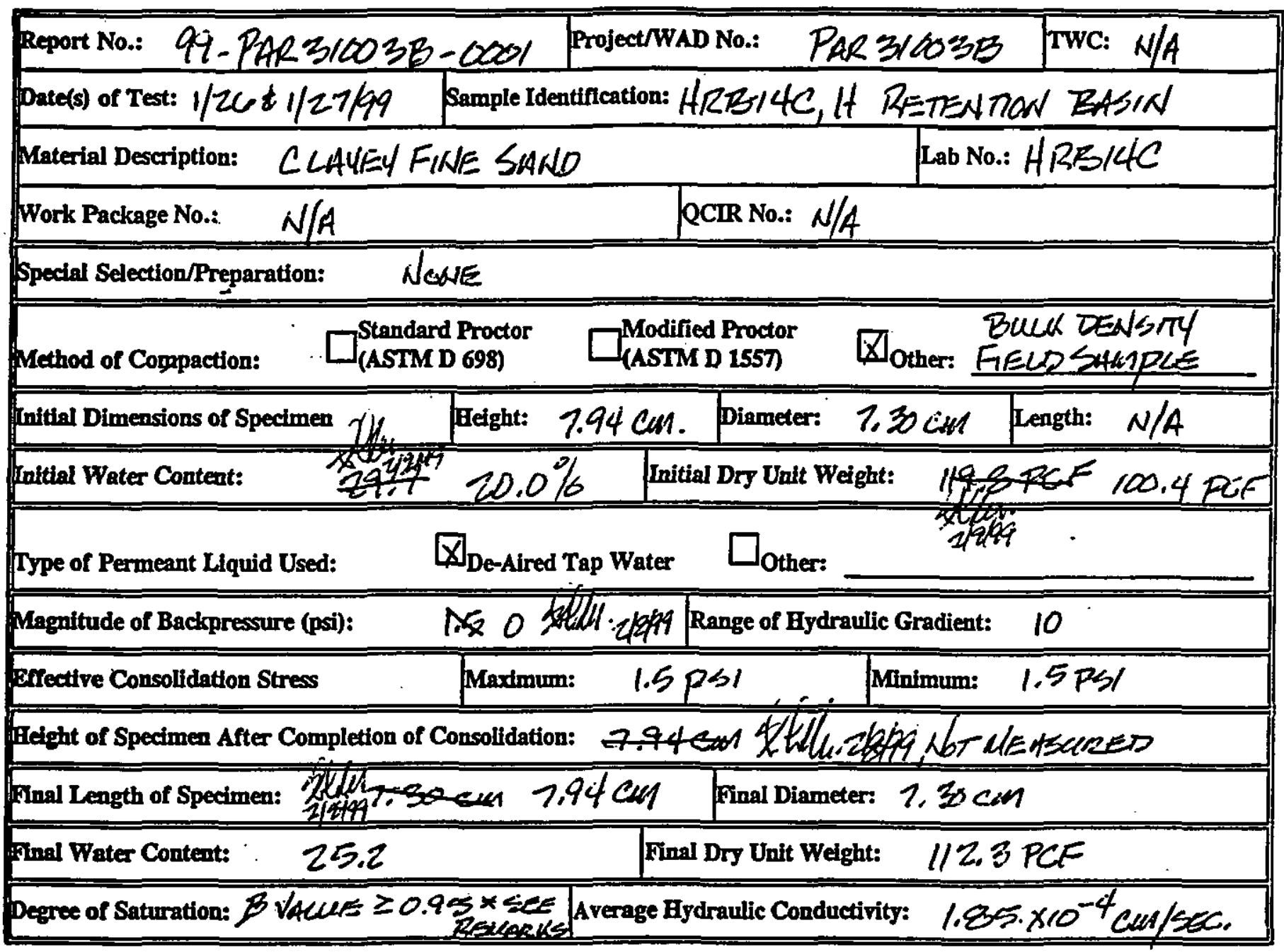

Calculations

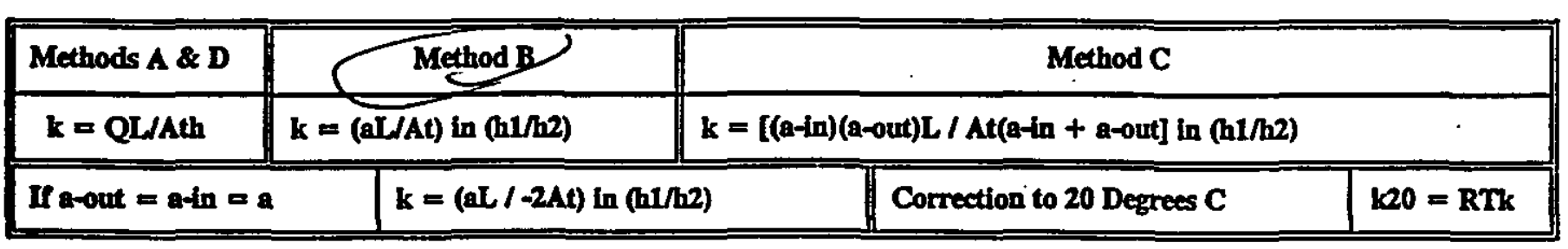

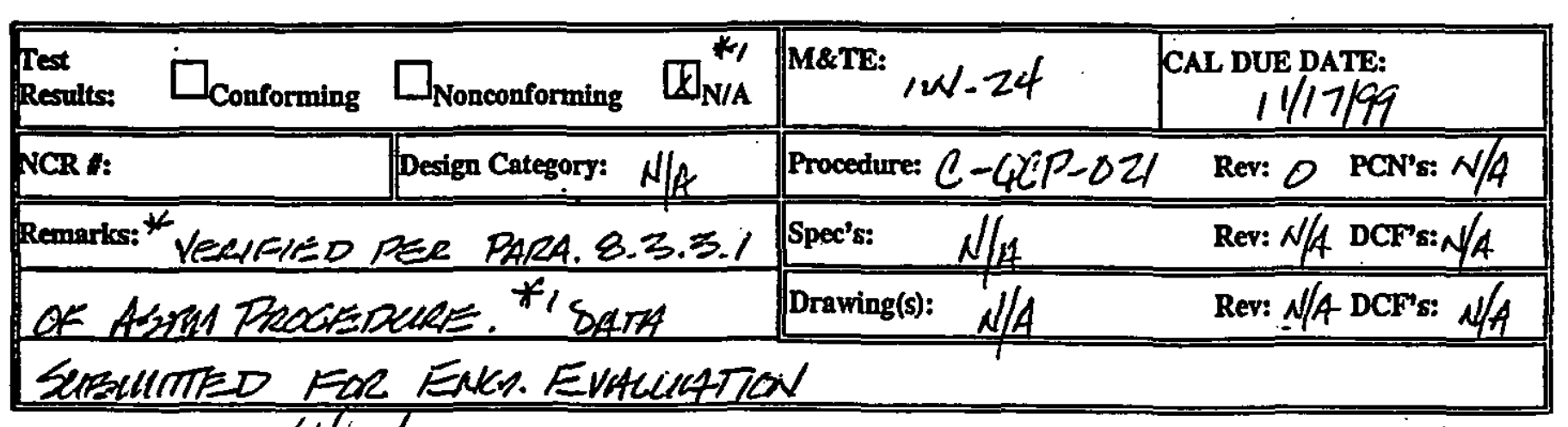

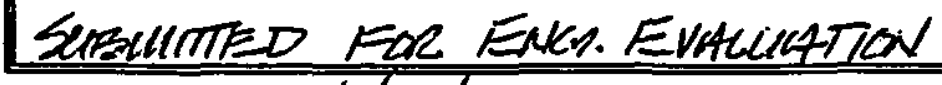

inspector: Wh.tweype

Level: III Date: 3/3/69

Reviewer:

Level: II Date: $323-49$ 


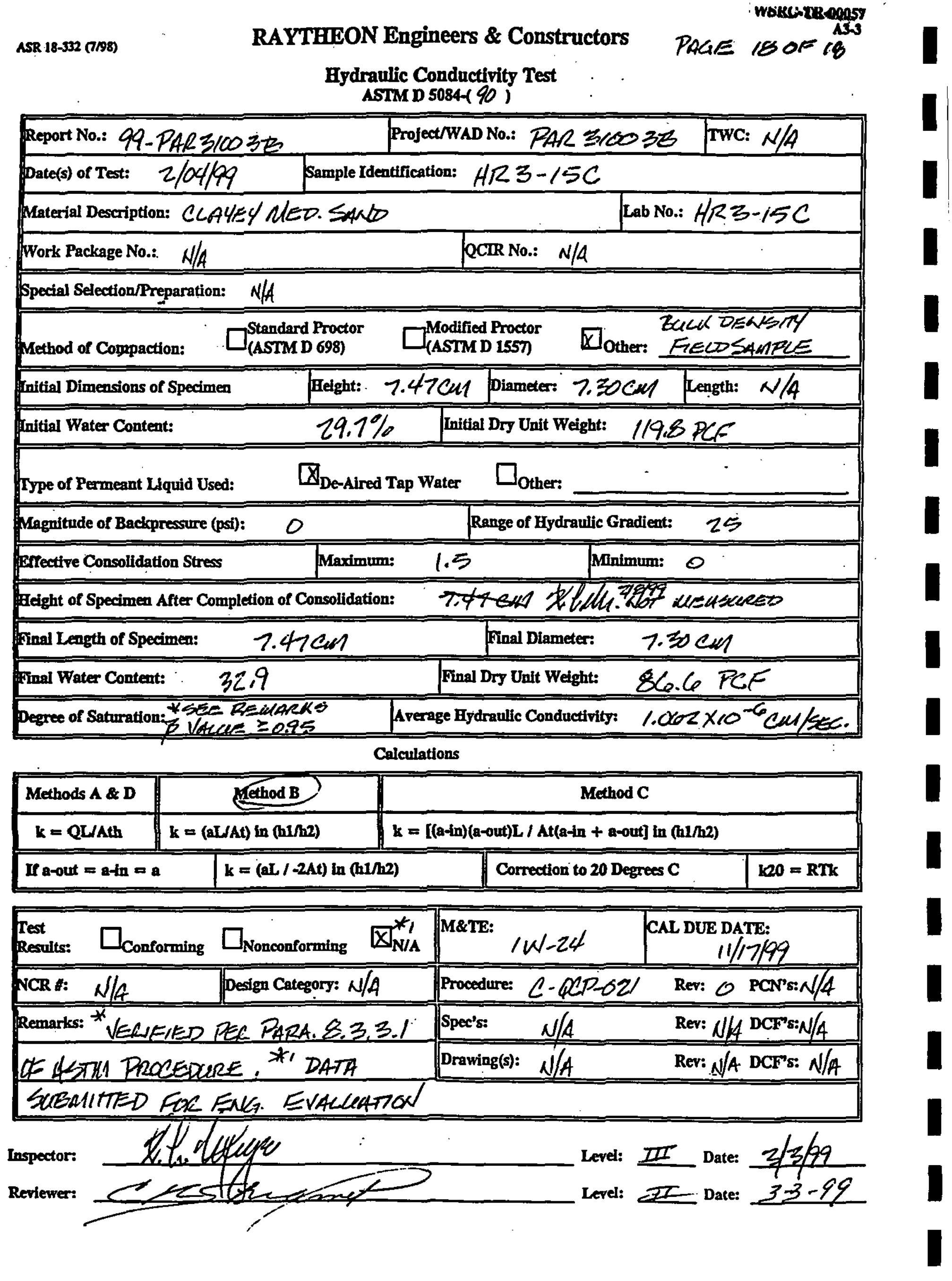


Hydraulic Conductivity Test

ASTM D S084- (90)

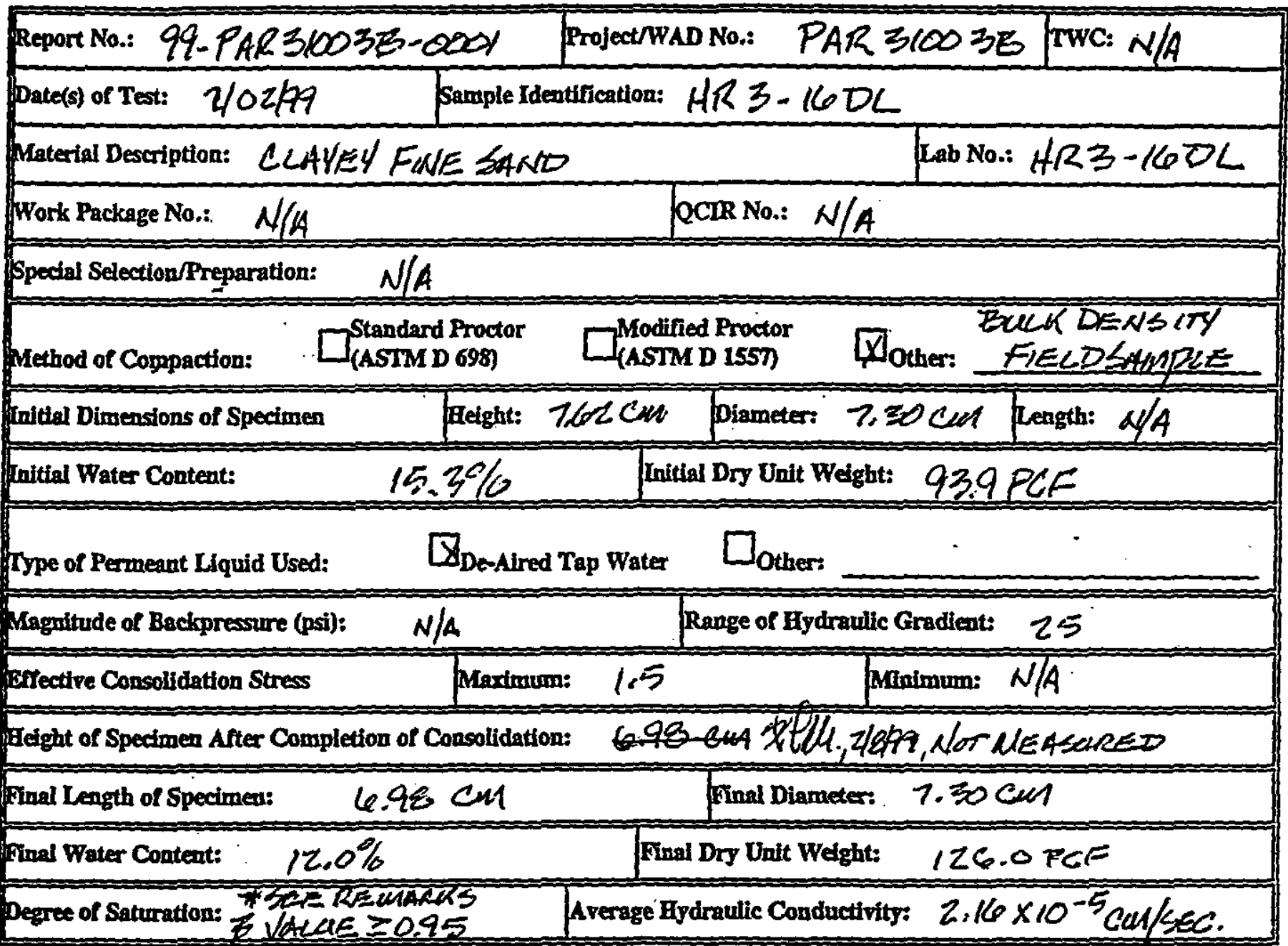

\section{Calculations}

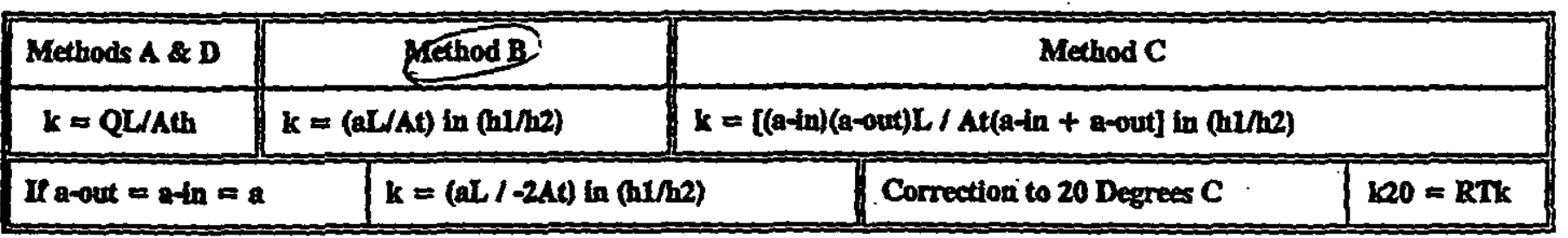

\begin{tabular}{|c|c|c|}
\hline $\operatorname{Rest}_{\text {Results: }} \square_{\text {Conforming }} \square_{\text {Nonconforming }} \square_{\text {N/A }}^{* /}$ & M\&TE: $\quad 1 W .24$ & $\begin{array}{r}\text { CAL DUE DATE: } \\
11 / 17 / 99\end{array}$ \\
\hline Desigu Category: $N / A$ & Procedure: $C-Q C R D Z$ & Rev: 0 PCANs:N/A \\
\hline Remarics: * VEREIED PER FRA 8.3.3.1 & Spec's: N/14 & Rev: $N / A D C r s: N / A$ \\
\hline OE ASTII PROEETURE, *I DATA & Drawing(s): $N / 4$ & Rev: N/ADCF's: N/A \\
\hline
\end{tabular}

Inspector:

Reviewer:

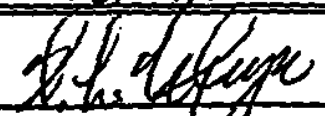

$\rightarrow$ rass
Level: III Date: z/3/99

Level: IF Date: $3-3-99$ 
ASR 18-332 (7/98)

RAXTHEON Engineers \& Constructors

WSRCARRO005T

Hydraulic Conductivity Test ASTM D 5084 ( 9D)

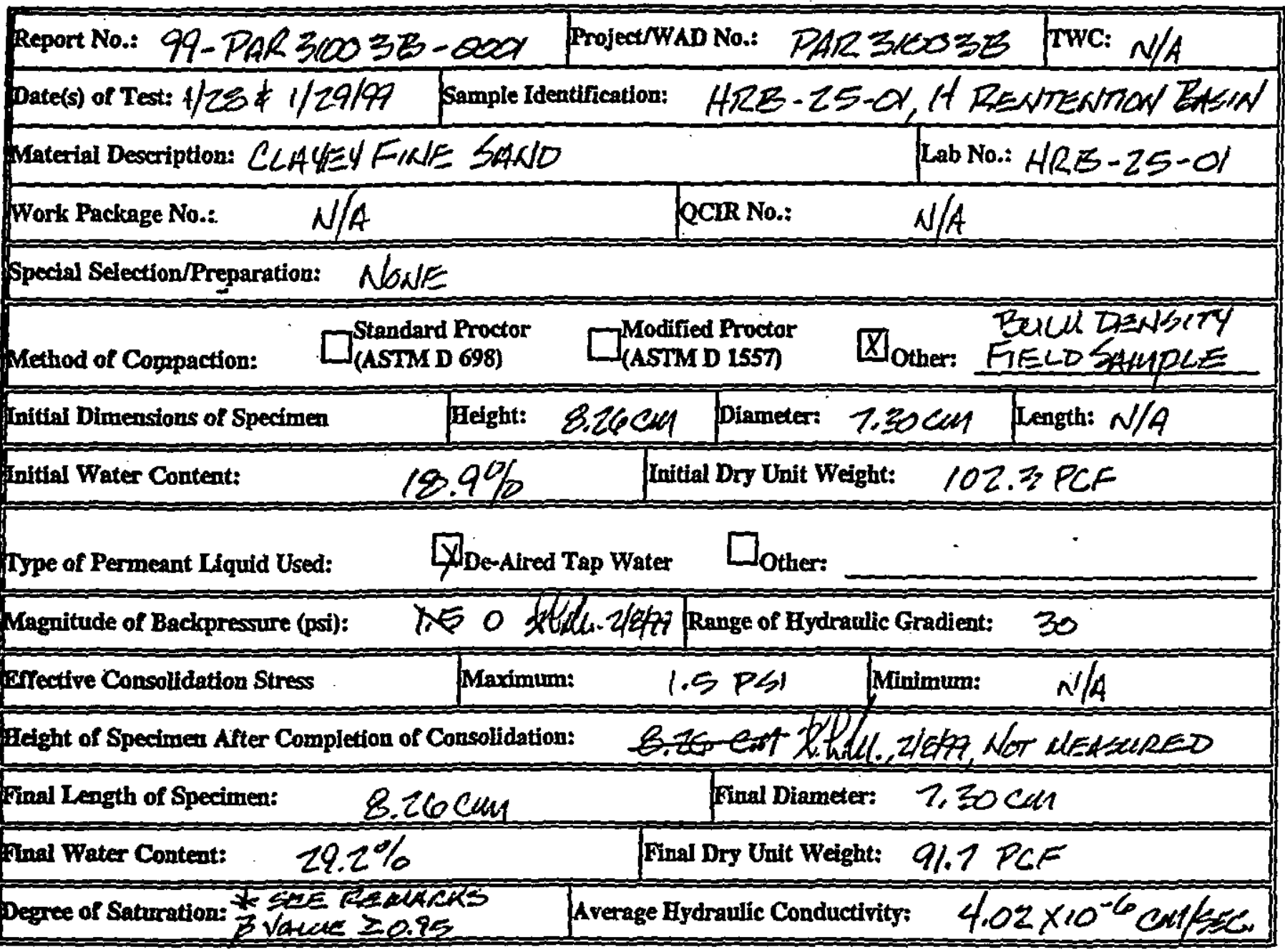

Calculations

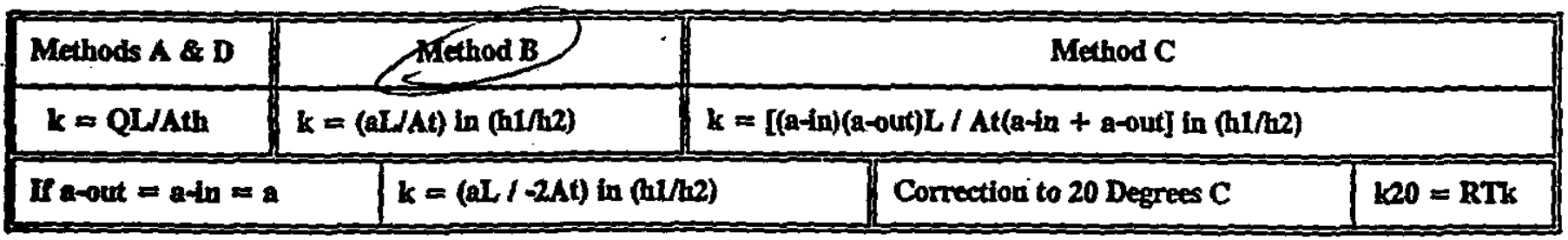

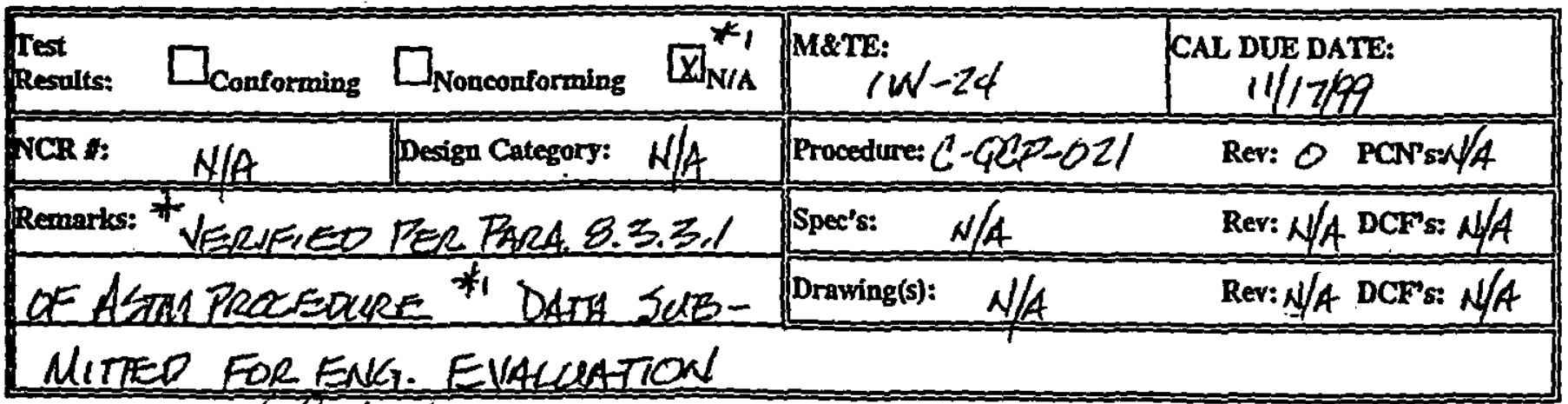

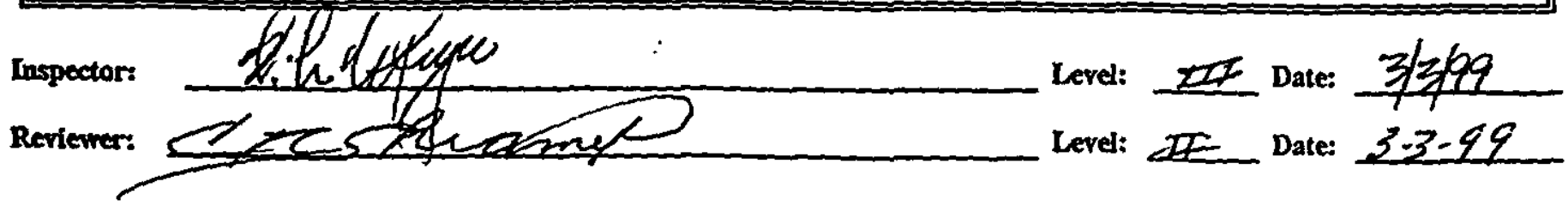


Hydraulic Conductivity Test ASTM D 5084-190 )

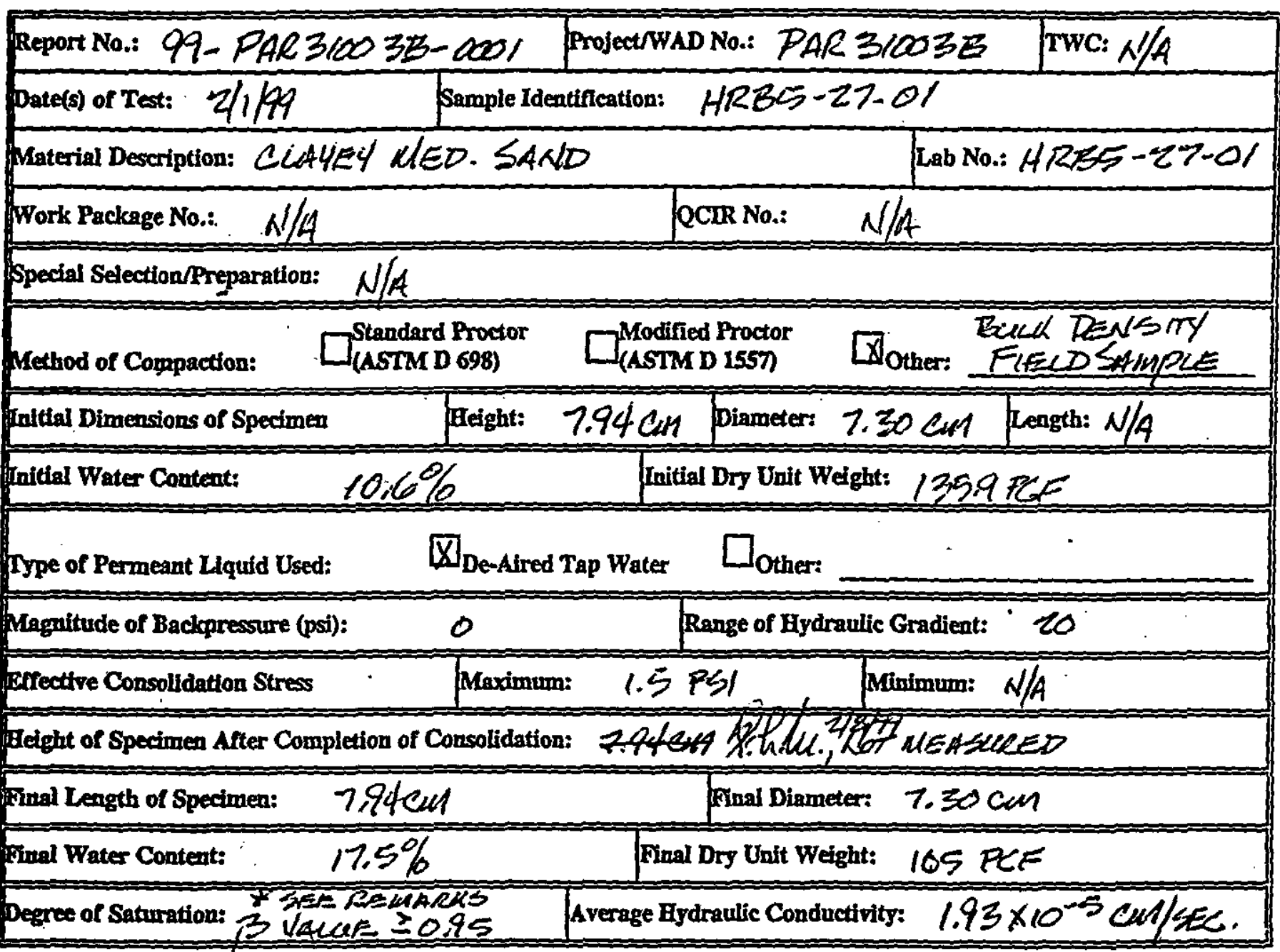

Calculations

\begin{tabular}{|c|c|c|c|c|}
\hline Methods A \& D & Method B & \multicolumn{3}{|c|}{ Method C } \\
\hline$k=$ QWAth & $k=(a L / A t) \ln (h 1 / \mathrm{hz})$ & \multicolumn{3}{|c|}{$k=[(a-i n)(a-o u t) L / A t(a-i n+a-o u t]$ in $(\mathrm{a} 1 / \mathrm{k} 2)$} \\
\hline If a-out $=\mathrm{a}$-in $=\mathrm{a}$ & \multicolumn{2}{|c|}{$k=(a L /-2 A t)$ in $(\mathrm{Bl} / \mathrm{A} 2)$} & Correction to 20 Degrees C & $120=\mathrm{RTK}$ \\
\hline
\end{tabular}

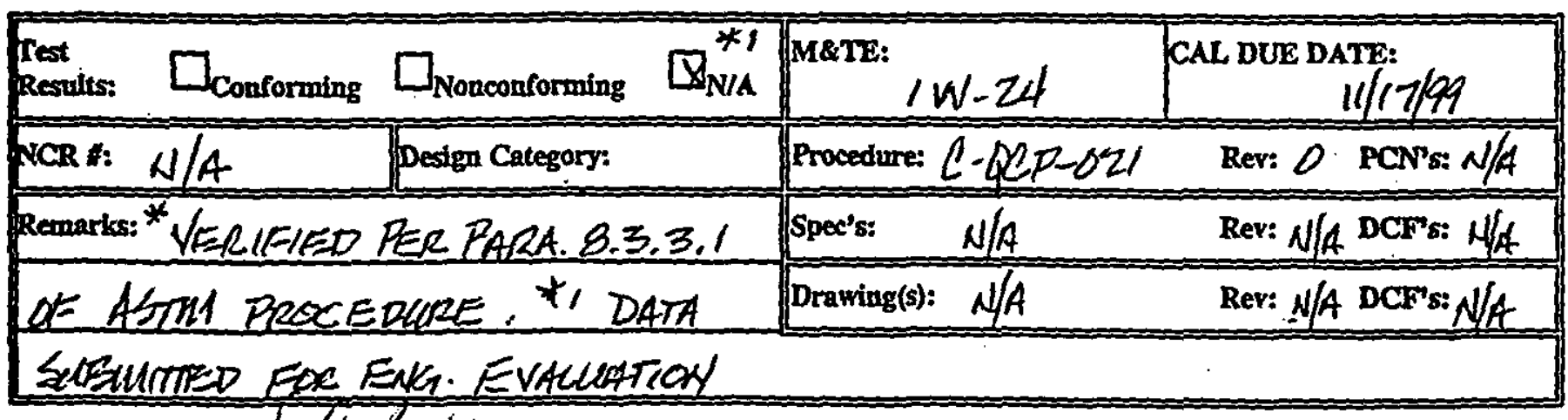

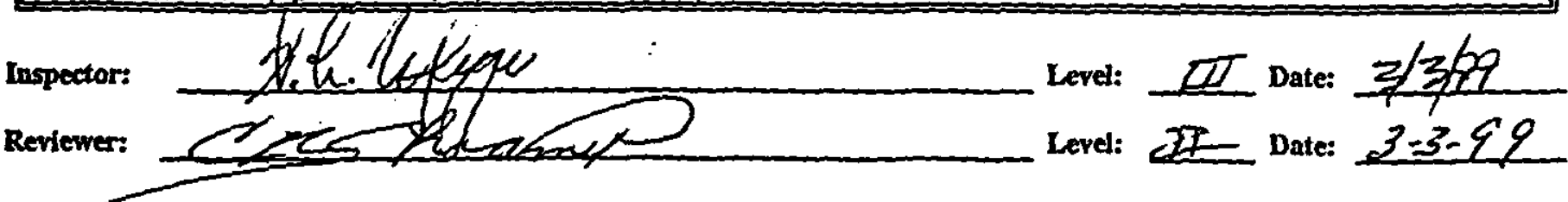




\section{APPENDIX 4.}

Exchangeable Acidity DATA Sheets 


\section{Summary of Data Sheet for Exchangeable Acidity Tests}

Vol Vol.0.01N pH after $\mathrm{H} 202$ Boiling Vol. $0.02 \mathrm{~N}$ Exchangeable

Sample Sample corrected Initial $\mathrm{H} 2 \mathrm{So3}$ addition Added Time NaOH Final Acidity Sample $\mathrm{ID}$ volume weight for solids $\mathrm{pH}$ (m) of $\mathrm{B2SO4}$ (drops) (min) (ml) pH

\begin{tabular}{|l|c|c|c|c|c|c|c|c|c|c|c|}
\hline HRB-14-C & 50 & 50.1537 & 49.85 & 4.42 & 0.50 & 3.60 & 5 & 4 & 0.70 & 8.22 & 90.3 \\
\hline HR3-15C & 50 & 50.019 & 49.98 & 6.24 & 4.00 & 4.00 & 55 & 38 & 3.80 & 8.22 & 360.1 \\
\hline HR3-16DL & 50 & 50.2715 & 49.73 & 5.89 & 1.50 & 3.70 & 10 & 11 & 2.00 & 8.21 & 251.4 \\
\hline HRB5-25-01 & 50 & 50.001 & 50.00 & 8.23 & 8.50 & 4.01 & 30 & 30 & 5.10 & 8.21 & 170.0 \\
\hline HRB5-27-01 & 50 & 50.3164 & 49.69 & 8.56 & 4.80 & 4.00 & 30 & 30 & 3.10 & 8.20 & 140.9 \\
\hline Blank & 50 & 50 & 50.00 & 5.41 & 0.10 & 4.01 & 5 & 4 & 0.20 & 8.2 & 30.0 \\
\hline
\end{tabular}

$\begin{array}{cccccccc} & \text { Vol } & \text { Vol, 0.01N } & \text { pH after } & \text { H2O2 } & \text { Boiling Vol. } 0.02 \mathrm{~N} & \text { Exchangeable } \\ \text { Sample Sample corrected Initial } & \text { H2So3 } & \text { addition } & \text { Added } & \text { Time NaOH } & \text { Final } & \text { Acidity }\end{array}$

Sample I
\begin{tabular}{|l|c|c|c|c|c|c|c|c|c|c|c|c|}
\hline HRB-14-C & 50 & 50.1588 & 49.84 & 4.48 & 0.30 & 4.00 & 5 & 4 & 1.00 & 8.22 & 170.5 \\
\hline HR3-15C & 50 & 50.05 & 49.95 & 6.46 & 3.30 & 4.01 & 10 & 13 & 2.80 & 8.22 & 494.5 \\
\hline HR3-16DL & 50 & 50.1623 & 49.84 & 5.91 & 1.00 & 4.00 & 15 & 18 & 1.70 & 8.21 & 240.8 \\
\hline HRB5-25-01 & 50 & 50.0375 & 49.96 & 8.24 & 2.00 & 4.02 & 5 & 5 & 1.90 & 8.21 & 180.1 \\
\hline HRB5-27-01 & 50 & 50.1228 & 49.88 & 8.6 & 1.75 & 4.01 & 10 & 13 & 1.40 & 8.20 & 105.3 \\
\hline
\end{tabular}




\section{APPENDIX 5.}


Unoffical Results Report By Subaission By Operation Tuesday February 09, 1999

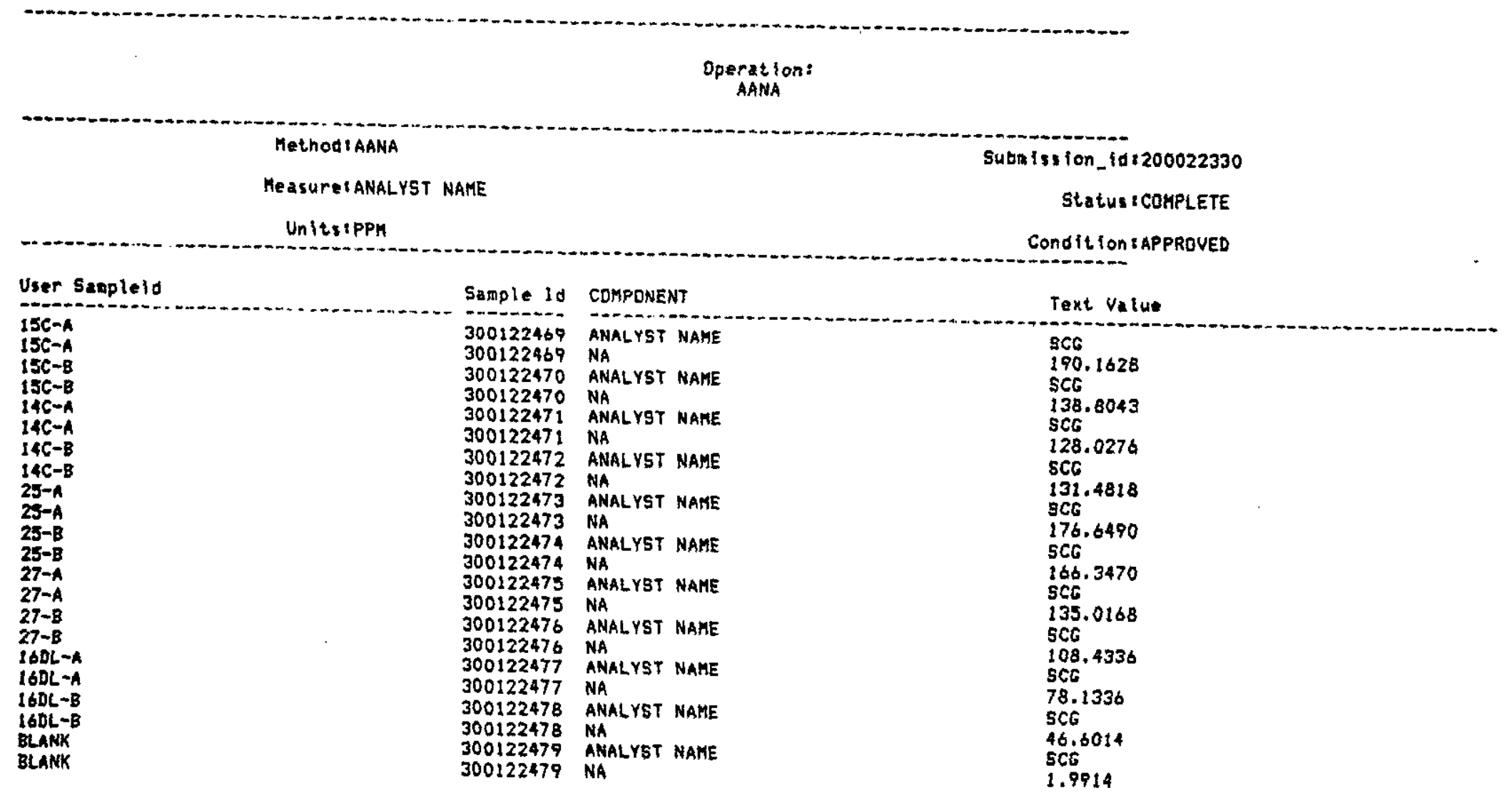




\section{APPENDIX 6.}

Chain of Custody for the HRB Shelby Tube Samples 
Savannah River Technology Center

Analytical Development Section (773-A) Analysis Request
CHRISTINE WANGFORD LANGTO PHONE: 5- 5806

WSRC-TR-0005

A6:

(Surcharge Applied For 24 And 48 Hours Turnaround Requests)

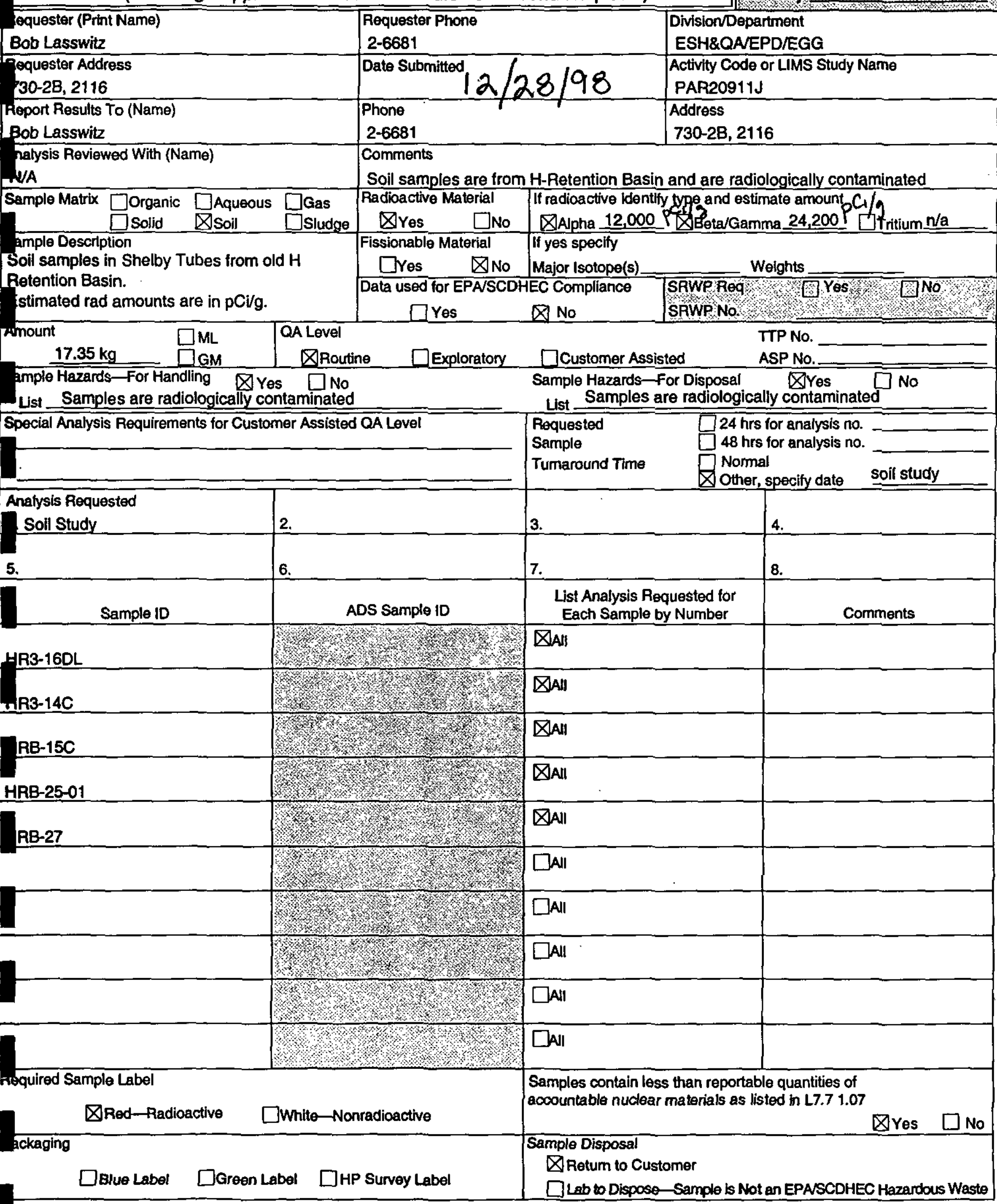

Aporog

onagion on

S ubmistion it

Siling $6 y$

DivisionDepartment

PAR20911J 


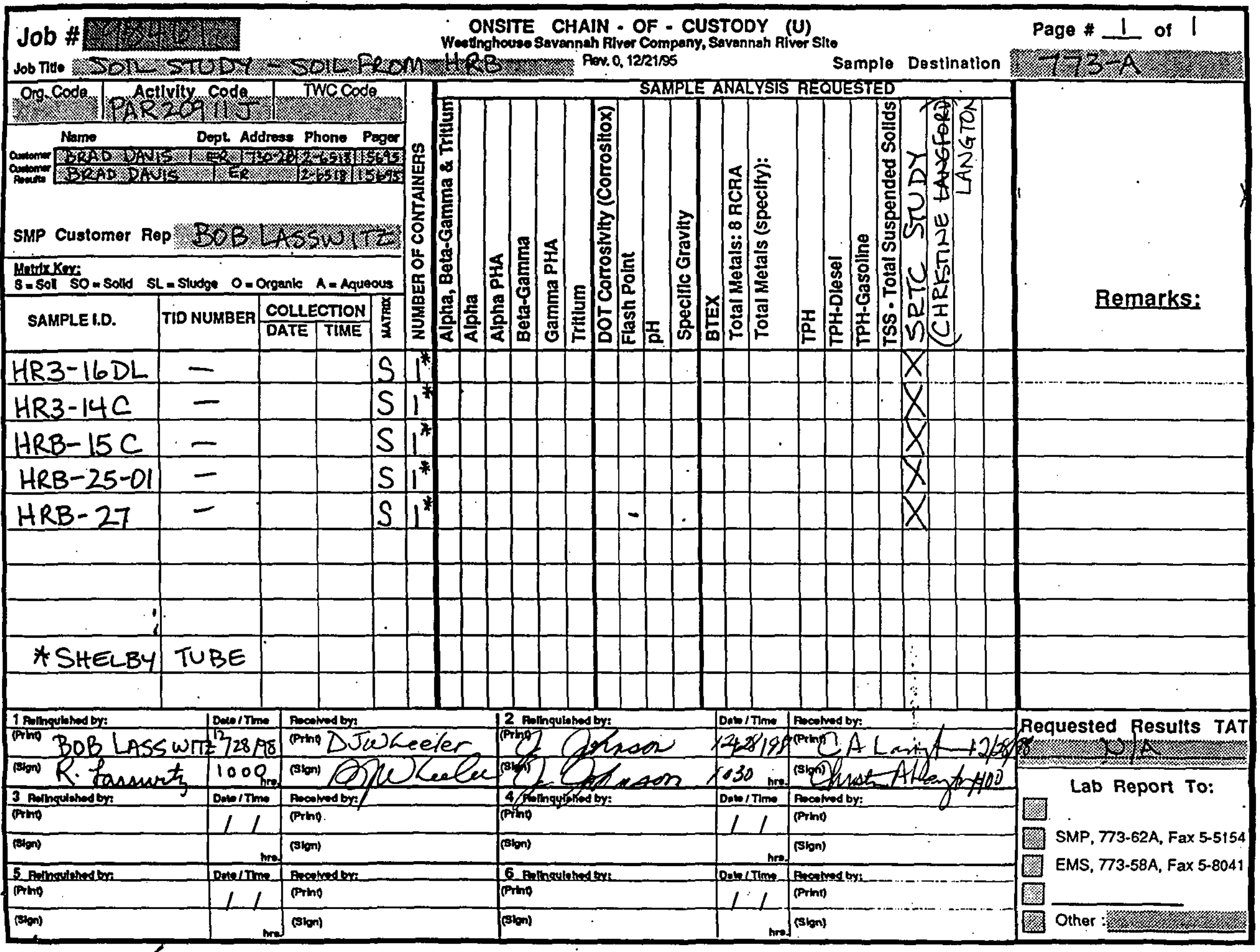


February 11, 1999

To: B. K. Davis, 730-2B

cc: B. T. Butcher, 773-43A

W. E. Stevens, 773A

W. L. Tamosaitis, 773-A

L. Papouchado, 773-A

C. G. May, $773-43 \mathrm{~A}$

L. M. Nelson, 773-43A

P. E. Lowe, 773-41A

R. F. Blundy, 730-2B

L. A. Bagwell, 730-2B

D. W. Nix, 730-2B

S. A. Kautz, 730-2B

W. L. Mhyre, $717-5 \mathrm{~N}$

M. A. Ditullio, 717-5N

[STI.4 Copies) 703-43A

File ( 2 copies) 
Title

Geotechnical Analysis of Five Shelby Tube Samples from H-Area Retention Basin(U)

\begin{tabular}{|l|l|l}
\hline $\begin{array}{l}\text { Primary Author/Contact (Must be WSRC) } \\
\text { C. A. Langton }\end{array}$ & $\begin{array}{l}\text { Location } \\
773-43 A\end{array}$ \\
\hline $\begin{array}{l}\text { Organization Code } \\
\text { L3230 }\end{array}$ & $\begin{array}{l}\text { Organization (No Abbreviations) } \\
\text { Savannah River Technology Center }\end{array}$ \\
\hline
\end{tabular}

Other Authors

W. L. Mhyre

Has an invention disclosure been submitted related to this information? [] Yes [] No

Disclosure No. (If Known)

Title

Do you intend to submit an invention disclosure? $[$ Yes $\square$ No If yes, projected date

Information Product Description

Conference/Meeting/Presentation

$\bigotimes$ Report Type

QQuarterly $\square$ Annual $\square$ Final $\square$ other

[ Semiannual $\bigotimes$ Technical $\square$ Topical

Report Dates thru

Meeting Title (No Abbreviations)

[Conference Type
$\square$ Abstract
$\square$ Conf Paper
$\square$ Published Proceedings
Eother

$\square$ Slides

[] Journal Article (Journal Name)

$[$ Videotape/Multimedia

External Web Page

$\square$ Software (Additional forms are required (ESTSC F1 and F2)).

References $\square$ In Public Literature $\square$ Routing Concurrently OApproved for Release $\square$ Other

1 understand that for the infof mation in this material to be given external disbribution, approvals by both WSRC and, as appropriate, DOE-SR are required. Distribution (verbally or published) mystbe in accordange yith poiigies set torth in WSRC management requirements and procedures (MRP 3.25 ) and in DOE-SR orders, and the content of the external disybution must beffopted to that actually approved.
Author's signature
$=\frac{3-11-99}{\text { Date }}$

\section{Approvals by Author's Organization}

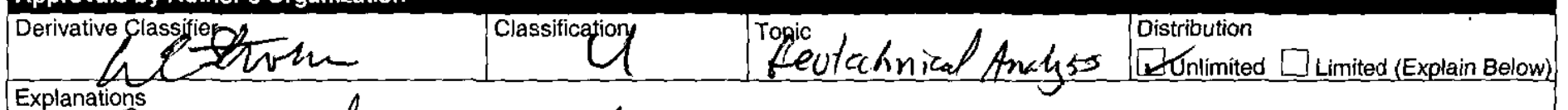

Explanations

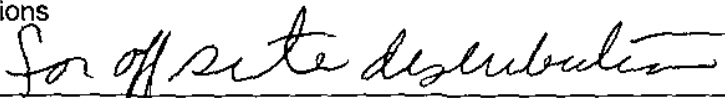

I understand and hay elconsidered whether any potential intellectual property rights (patents, copyrights, etc., in accordance with MP 1.09 and MRP 1.07) or any contractural barriers (CRADAs, Work for Others, etc.) may be involved before authorizing that this document be proposed for public release. If any

concerns were identified, these have been discussed and resolved with General Counse a. Stoveris

Manager's Name (Print)

Q E Hurua Manager's Signature

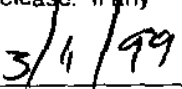

Classification Information (To be Completed by Classification Reviewer)
Classification (Check One for Each)
Overall
Abstract
$\square \mathrm{s} \square \mathrm{c}$
$\square$ UCNI

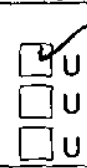
Title
$\square \mathrm{s} \quad \square \mathrm{c}$
[ UCNI

WSRC Classification Officer's Name herinta

a SGIFICATION ANALYST

Classification Guido Topics

Export Control Review (To be Completed by Export Control Reviewing Official)

Export Control Related

$$
\text { Gres UNo }
$$

Export Control Reviewer's Name (Print)

TR. TOLGHENOHA A A8SIFICATION ANALYS

UC/C Number 50

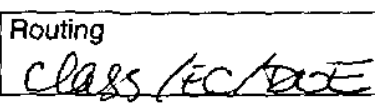

Expge Entroj Reviewer's Signature STI Programt Use Only Deadline Date for Approval

Date Submitted

$(m / d / y)$ thru $(m / d / y)$

Sponsor
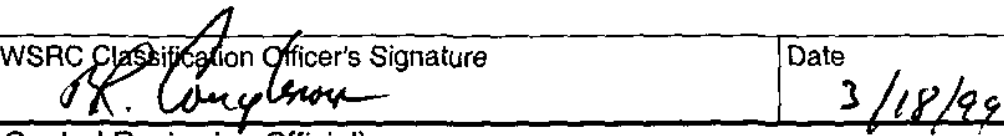

NOTE OSR 17-8 must be completed in addition to this form when submitting information for review and approval.

$$
\text { Kyyends: ser courerpege }
$$


March 18, 1999

WSRC-TR-99-00057

MSD-STI-97-4198

Ms. W. F. Perrin, Technical Information Officer

U. S. Department of Energy - Savannah River Operations Office

Dear Ms. Perrin:

\section{REQUEST FOR APPROVAL TO RELEASE SCIENTIFICITECHNICAL INFORMATION}

The attached document is submitted for classification and technical approvals for the purpose of external release. Please complete Part II of this letter and return the letter to the undersigned by 4/30/99. The document has been reviewed for classification and export control by a WSRC Classification staff member and has been determined to be Unclassified.

I. DETAILS OF REQUEST FOR RELEASE

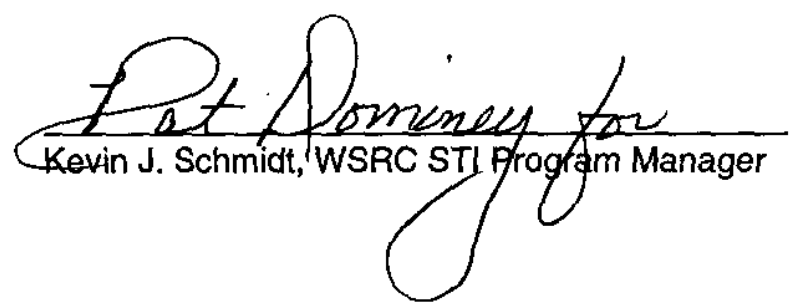

Document Number: WSRC-TR-99-00057

Author's Name: C. A. Langton

Location: $773-43 \mathrm{~A}$

Phone 5-5806

Department: SRTC

Document Title: Geotechnical Analysis of Five Shelby Tube Samples from H-Area Retention Basin

Presentation/Publication:

Meeting/Journal:

Location:

Meeting Date:
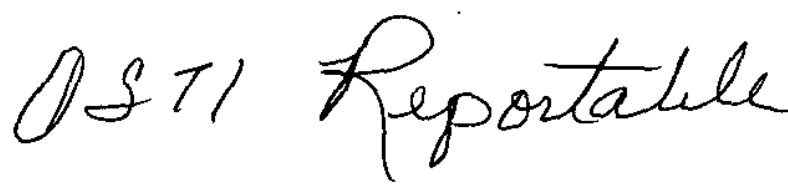

II. DOE-SR ACTION

Date Received by TIO

X Approved for Release

$\square$ Approved Upon Completion of Changes

Approved with Remarks

marks:

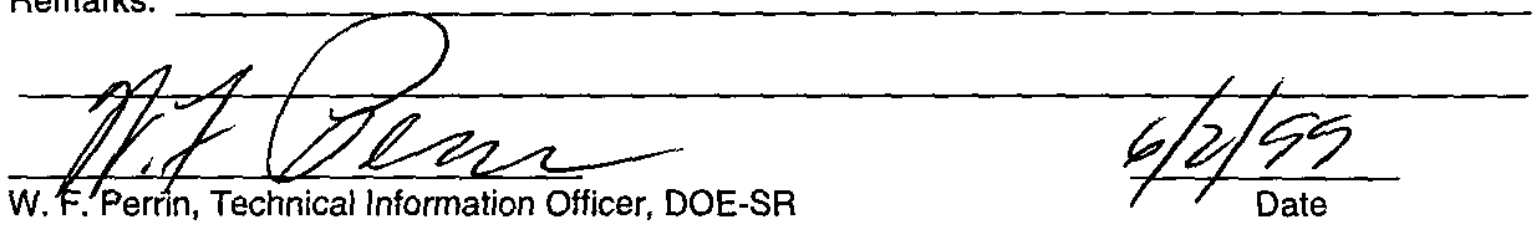


RECORD STATUS (select one):

$X$. New ......Revised Data ..... Zevised STI Product

Part I: STIPRODUCT DESCRIPTION

A. STI PRODUCT TYPE (select one)

X.. 1. Technical Report
a. Type:
Topical
$\square$ Semiannual
Annual $\triangle$ Final
Other (specify)
b. Reporting Period ( $\mathrm{mm} / \mathrm{dd} / \mathrm{y} y \mathrm{y}$, thru

\section{Conference}

a. Product Type: ...... Conference Proceedings ..... Conference Paper or Other (abstracts, excerpts, etc.) _

b. Conference Information (title, location, dates)

.... 3. Software Manual ( The actual software package should be made avallable simultaneously. Follow instructions provided with ESTSC $F$ i and ESTSC F 2.)

4. Journal Article
a. Type: $\quad$ X_Announcement citation oniy
-Preprint
_. Postprint
b. Journal Name
c. Volume
d. Issue
e. Serial ídentifier (e.g., ISSN or CODEM

5. S\&T Accomplishment Report

6. Book

7. Patent Application
a. Date Filed $(\mathrm{mm} / \mathrm{d} d / \mathrm{y} y \mathrm{y})$
b. Date Priority $(m m / d d / y / y y)$

c. Patent Assignee

..... 8. Thesis/Dissertation

B. STI PRODUCT TITLE Gegtechnical.Analysis.of.Five.Shellhx.Tuhe.Samples.from.H-Area.Retentionn.Rasin

C. AUTHOR(s) C. A. - tuangton

\section{E-mail Address(es):}

D. STI PRODUCT IDENTIFIER
1. Report Number(s) WSRC-:T.R-99-0.0057.
2. DOE Contract Number(s) _RE:AC09-96\$R18500
3. R\&D Project ID(s)
4. Other Identifying Number(s)

E. ORIGINATING RESEARCH ORGANIZATION Savannah River Site.

F. DATE OF PUBLICATION (mm/dd/yyYy)

G. LANGUAGE (if non-English) English

(Grantees and Awardees: Skip to Description/Abstract section at the end of Part )

H. SPONSORING ORGANIZATION

I. PUBLISHER NAME AND LOCATION (if other than research organization)

Availability (refer requests to [if applicablel)

J. SUBJECT CATEGORIES (iist primary one first) $\quad \mathbf{5 . 8}$

Keywords H-Area.Retention.Basin .Geotechnical.Analxsis. Soll.Characterization.

K. DESCRIPTION/ABSTRACT

Geotechnical and geochemical analyses were performed on five Shelby tube samples collected in the $H$-Area

Retention Basin (HRB) during July and August of 1998. The samples were collected as part of the HRB

characterization study. The test results, which are documented in this report, will be used to support the HRB

contaminant fate and transport modeling/analysis and to evaluate remedial options. The results will also be used as a base line for future treatability studies. 


\section{ANNOUNCEMENT OF U. S. DEPARTMENT OF ENERGY (DOE) SCIENTIFIC AND TECHNICAL INFORMATION (STI)}

Part II: STI PRODUCT MEDIAFORMAT and LOCATION/TRANSMISSION

A. MEDIAFORMAT INFORMATION

1. Medium of STI product is:

X.. Paper

...... Electronic document

...... Computer medium

.... Audiovisual material

2. Size of STI product

3. File format:
a. If electronic document is posted at site, indicate: $\square$ html $\square$ pdfn $\square$ sgml $\square \times \mathrm{xml}$
b. If electronic document is transmitted to OSTl, indicate: $\square$ html $\square$ pdin $\square$ pdfi $\square$ msword
_TIFFG4 _.WP-indicate Version (5.0 or greater)
—MS Word-indicate Version (5.0 or greater)
platform/operating system

4. If computer medium or audiovisual material:
a. Quantity/type (specify)
b. Machine compatibility (specify)
c. Sound
(yes)
d. Color
(yes) e. Tables/Graphics
(yes)
t. Other information about product format a user needs to know:

\section{B. LOCATIONTRANSMISSION INFORMATION}

1. STI Product is available at site: Unique URL (of specific STI Product)

2. STI Product is being transmitted to OSTI:

a. _ Electronically via FTP

b. _ Via Mail or shipment (e.g., Federal Express) (Paper products, electronic documents on CD-ROM, diskettes, videocassettes, etc.)

3. Information Product Filename (of transmitted electronic format)

C. ADDITIONAL INFORMATION (concerning media/format or location/transmission; for OSTI internal us $\theta$ only):

(Grantees and Awardees: Skip to Contact section at the end of Part III)

Part III: STI PRODUCT REVIEW? RELEASE INFORMATION

A. ACCESS LIMITATION

X..... 1. Unlimited Announcement (available to U.S. and non-U.S. public)

........ 2. OpenNet (use OpenNet guidance for below):

a. If additional source other than making it available through NTIS:

e. OpenNet Document Type

(1) Accession Number

(2) Document Location

t. OpenNet Document Keywords

b. Field Office Acronym

c. Declassification date $(\mathrm{mm} / \mathrm{dd} / \mathrm{yyyy})$

g. OpenNet Aưdressee

d. Declassification Status:
Declassified

3. U.S. Dissemination Only

4. Copyrighted material; Are there any restrictions based on copyright?

yes

no. If yes, list the restrictions

5. Small Business innovation Research (SB/R) Release date ( $\mathrm{mm} / \mathrm{dd} / \mathrm{y} y \mathrm{yy}$ )

6. Small Business Technology Transter (STTR) Release date (mm/dd/yyy)

7. Proprietary/Trade Secret

8. Patent Pending

9. Protected data

CRADA

Other (specify)

Release date $(\mathrm{mm} / \mathrm{dd} / \mathrm{yyyy})$

........ 10. Official Use Only (OUO)

....... 11. Program-Directed Special Handling (specify)

12. Export ControlitTAR/EAR

13. Unclassified Controlied Nuclear intormation (UCN)

14. Classified Classification LevelCatedorv of:
a. This form $\mathbf{U}$.
b. The STI Product Unclassified

15. Other information relevant to access (specify; for OSTI intemal use only))

B. OTHER (information useful to include in published announcement record which is not suited for any other field on this form)

C. CONTACT AND RELEASING OFFICIAL

1.Contact (if appropriate, the organization or site contact to include in published citations who would receive any extemal questions about the content of the

STI Praduct or the research information contained therein)

Name and/or Position

E-mail

K.J. Schmidt, Manager STI Program \& Site Support

Organization Westinghouse Savannah River Company Phone $\_$(803) 725-2321

2. Releasing Official $\mathbf{X}$ I verify that all necessary reviews have been completed (e.g. Patent, Copyright, ECI, UCNI, etc.)

Released by (name) K.J. Schmidt

Date $(\mathrm{mm} / \mathrm{d} d / \mathrm{y} / \mathrm{y} / \mathrm{y})$

E-Mail

Phone 